\title{
Forms, function, and use of Early Eneolithic pottery and settlement structures from Zgornje Radvanje, Slovenia
}

\author{
Bine Kramberger \\ Ljubljana, SI \\ bine.kramberger@siol.net
}

\begin{abstract}
This paper discusses the use of ceramic objects in daily life in the Early Eneolithic period, based on ceramic assemblages from the settlement at Zgornje Radvanje in Maribor. The possible function of individual pottery types was studied through typological analysis, pottery production methods, traces of secondary burning and carbonized residues, and ethnographic parallels. The function of different types of settlement structure is discussed on the basis of statistical comparisons of the composition of ceramic assemblages.
\end{abstract}

IZVLEČEK - V članku razpravljamo o uporabi keramičnih predmetov v vsakdanjem življenju $v$ obdobju zgodnjega eneolitika, na podlagi keramičnih zbirov iz naselbine Zgornje Radvanje v Mariboru. Funkcijo posameznih keramičnih tipov smo raziskali s pomočjo tipoloških analiz, analiz načina izdelave keramike, sledov sekundarnega gorenja in karboniziranih ostankov ter tudi z iskanjem etnografskih vzporednic. Na podlagi statističnih primerjav sestave keramičnih zbirov pa razpravljamo o funkciji različnih tipov naselbinskih struktur.

KEY WORDS - Early Eneolithic; settlement; Zgornje Radvanje; settlement structures; pottery; functional analyses

\section{Introduction}

The use of ceramics, mainly vessels, became a popular topic in Slovenian archaeology of the Neolithic and Eneolithic periods in the last ten years. These investigations are primarily based on biochemical studies, mainly of lipids absorbed by pottery (Ogrinc, Budja 2005; Šoberl et al. 2008; 2014; Ogrinc et al. 2012; 2014; Mlekuž et al. 2012; 2013; Budja et al. 2013), and also on analysis of visible charred residues deposited on the vessels surface (Ogrinc et al. 2012.340-342; Šoberl et al. 2014.155, 158; Kramberger 2015). Biochemical studies may give us direct links between the vessels and the contents they originally held and thus can help not only to explain the actual function of individual ceramic finds, but also various other questions concerning pottery use. ${ }^{1}$ In parallel, the analysis of morphological characteristics of vessels, analysis of pottery manufacturing technology (techno-functional analysis), analysis of use-al- terations, studies of archaeological contexts (e.g., Ashley 2001; Wilson, Rodning 2002; Braun 2010; Boudreaux III 2010), as well as ethnographic analogy (e.g., Costin 2000; Hegmon 2000; Eerkens 2005. 80 ), although it may be unrecognised initially, can give us further indications about the intended use of prehistoric ceramics (see also Henrickson, McDonald 1983; Schiffer, Skibo 1987; Rice 1987.207232; Eerkens 2005.85-87, 96-97; Urem-Kotsou et al. 2002). Yet, until recently, Slovenian archaeologists placed relatively little emphasis on such approaches (Mlekuž et al. 2012.331-335; 2013.133139; Šoberl et al. 2014.150-164).

In this paper, we contribute to the continuous study of the use of ceramics in the Neo/Eneolithic period with a case study based on ceramic assemblages obtained at the Early Eneolithic settlement at Zgor-

1 For the methodological approach to biochemical studies of organic residues on pottery and possibilities that such an approach may offer, see, for example, Mihael Budja (2014). 
nje Radvanje. The research has two objectives: firstly, to define the pottery types and their possible function intended by potters (Rice 1987.207-232). Our considerations are based on analyses of vessel shapes and dimensions, of ceramic manufacturing technology, use alterations (traces of secondary burning, remains of carbonised residues) and ethnographic parallels. The second objective concerns the function of the different types of settlement structure excavated at Zgornje Radvanje; the discussion is based on statistical comparisons of the composition of ceramic assemblages.

\section{The site and its ceramic assemblage}

The Zgornje Radvanje site, situated in northeastern Slovenia, was excavated between 2007 and 2008, and in the year 2010. There is evidence showing that the area of the site was intermittently inhabited from the Eneolithic to the Early Modern Period, however, the biggest and the most prominent settlement dates to the Early Eneolithic Lasinja Culture (Koprivnik et al. 2009.16-18; Kramberger 2010; 2014.241-242, Fig. 15; Murko 2012.141-142; Arh 2012). The settlement of the Lasinja Culture was probably circular in form and consisted of around 23 settlement structures, some of which were clearly pit houses. Numerous smaller pits dating to the same period were found in their vicinity.

According to the radiocarbon dates, most of the Lasinja settlement, which was excavated in 2007 and 2008, existed for a short period around c. $4300 \mathrm{BC}$, while a single ${ }^{14} \mathrm{C}$ date of a sample from a post hole is somewhat younger, indicating activity on the site at the end of the $5^{\text {th }}$ and beginning of the $4^{\text {th }}$ millennium BC (Kramberger 2014.242-244). Part of the Eneolithic settlement, excavated in 2010, also dates to the $4^{\text {th }}$ millennium BC (Arh 2012.Figs. 10, 40, $61,65)$.

For the present study, we have chosen the ceramic assemblages from 17 different structures. These structures differ in their size, number of post holes and the presence/absence of fire places and hearths; therefore, it can be assumed that they were built in different ways, and perhaps served different purposes. The first type of structure is characterised by a deepening of a trapezoidal shape and a hearth or fire place (structures 17, 22 and 5; see also Kramberger 2010.311-312, Fig. 4; 2014.241, Fig. 16).
Only a few post holes were found on the edge of the pit, and because they were mostly very shallow, we assume, that they supported the roof (Fig. 1). The second type of structure also contained a fireplace; however, it is also characterised by deeper post holes (structures 9 and 20), which delineate a rectangle with at least two rooms (Fig. 2). ${ }^{2}$ Other structures chosen for our study did not contain fireplaces. Structures 8, 6 (Kramberger 2014.Fig. 17), 7 (Ibid. Fig. 19) and 4 (Ibid. Fig. 18) were about the same size as the buildings with hearths and fireplaces; structures 3, 11-15, 1 (Ibid. Fig. 20) and 19 were significantly smaller. Each structure was usually connected with a single deepening of a rectangular or oval shape, and post holes were found in the pit itself or on its edge. The only exceptions are small rectangular structures 11-15, because all of them relate to only one deepening and the cultural layer found in it, and were therefore probably contemporaneous.

Part of the Lasinja settlement excavated in 2007 and 2008 in Zgornje Radvanje yielded 26408 ceramic fragments (almost 300kg; Ibid. Fig. 26), while in the studied structures, a total of 14021 were found; yet we can recognise that they were found in each structure in a varying quantities (Fig. 3). 3 The number of ceramic fragments became significantly smaller after joining fragments during the reconstruction process, and eventually it was possible to determine
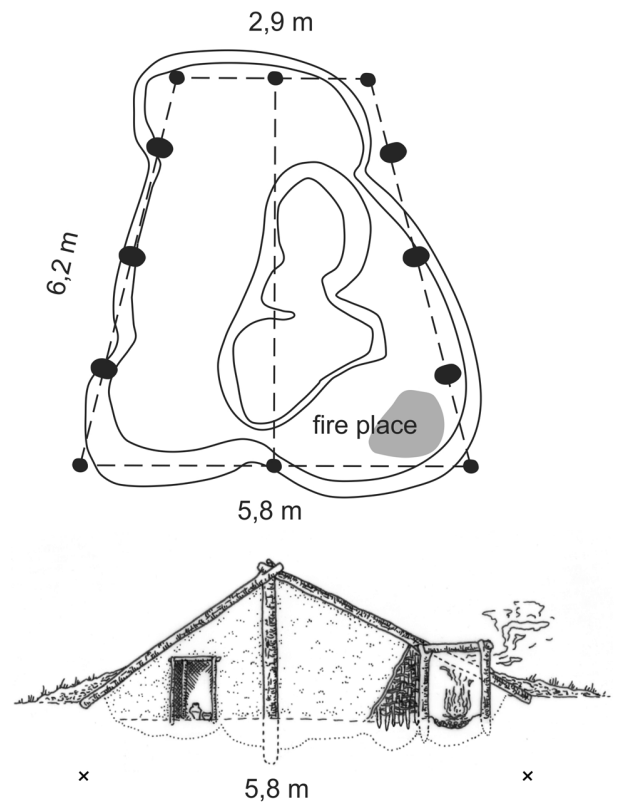

Fig. 1. Zgornje Radvanje. Reconstruction of the building (structure 22) with trapezoidal deepening and hearth.

2 In structure 20, the fireplace was found in the deepening of a structure, while in structure 9 , in its vicinity.

3 Most of the ceramic fragments not included in our study originate from less well-preserved structures, structures which were only partly excavated, or from smaller pits, but also from alluvia, palaeochannels and top soil. 


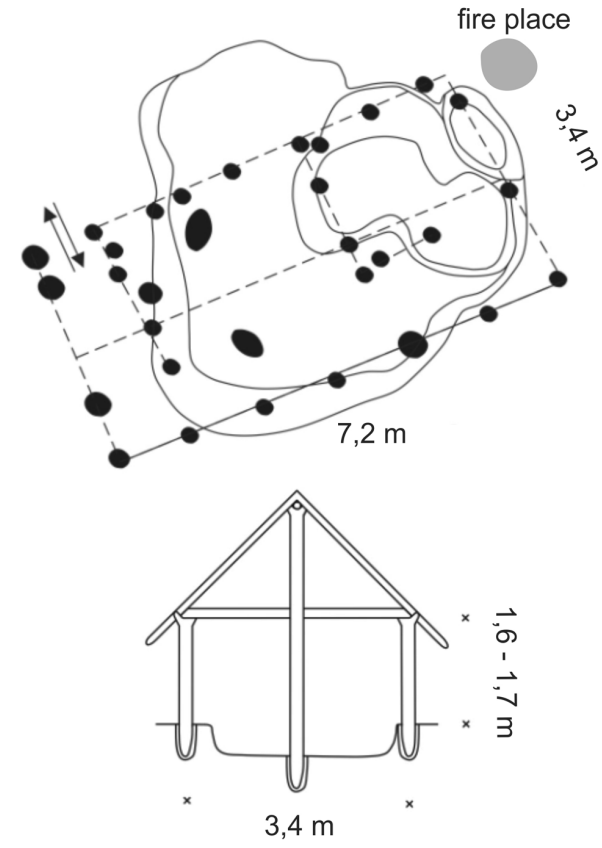

Fig. 2. Zgornje Radvanje. Reconstruction of the rectangular building (structure 9) with a fire place.

the basic shape of 699 ceramic finds, which form the basis for our study. These appear in 15 different basic types, which differ from each other in shape, size, the size of the opening in comparison to the maximum diameter, and in additional elements (i.e. feet, handles, appliqués, and spouts).

\section{Vessel shapes/sizes and function}

Ethnographic studies indicate that there is often a relationship between vessel shape and its use (Braun 1980.172; Hally 1986.268; Henrickson, McDonald 1983.630; Smith 1988.912). These studies have shown that people produce vessels of different shapes for particular purposes, because a vessel's morphology affects its performance in the daily activity in which it is used. The most important functional variables that affect a vessel's morphology are assumed to be the frequency with which a vessel's contents need to be accessed and the degree to which these contents need to be contained (Braun 1980. 172). In general, vessels with larger openings are produced when frequent access is of concern, and more restricted vessels when containing the contents is important (Ibid. 172; Henrickson, McDonald 1983.630-634; Smith 1988.914; Boudreaux III 2010.10). Thus, the first recognised pattern in our analysis of vessel shapes that needs to be pointed out is that there are two main groups of vessels, based on the relative size of their opening: vessels with necks, with openings smaller than $80 \%$ of the maximum diameter of the body, and vessels without necks, and openings bigger than $85 \%$ of the maximum diameter.

First, we present the group with openings smaller than $80 \%$ of the maximum diameter. The most common vessels in this group are larger two-handled vessels described as pots, which according to their size and quantity (31.76\%) could have been primarily as storage vessels (Fig. 4.L; see also Kramberger 2014.Pl. 7.122, Pl. 8.131, Pl. 9.146, 152; 2010.Pl. 2.9, 12, Pl. 3.13-15, 18, Pl. 7.47-49, Pl. 8.50-52, Pl. 9.52). There are three different groups of pots, based on their size. The first group consist of vessels with volumes between 12.1 and 15.4 litres; in the most common second group are vessels of volumes between 3.5 and 5.5 litres, while the third group consists of vessels with volumes between 0.8 and 2.3 litres (Apps. 1-2). The use of pots as storage vessels is also indicated by the biochemical analysis of organic residues preserved on similar pots from the Neo/ Eneolitic site at Moverna vas in Bela Krajina ( ̌oberl et al. 2014.164, Fig. 13). Namely, these analyses showed that some pots have one of the highest preserved lipid concentrations, which indicates that they were probably used to store fatty foodstuffs over an extended period.

Only five examples of bottle-like vessels, which have smaller openings than pots, ${ }^{4}$ and appliqué instead of handles appeared in the settlement structures (Fig.

4 The minimum diameter of pot necks is always greater than half of the maximum diameter of the vessel, while bottle-like vessels have narrower necks.

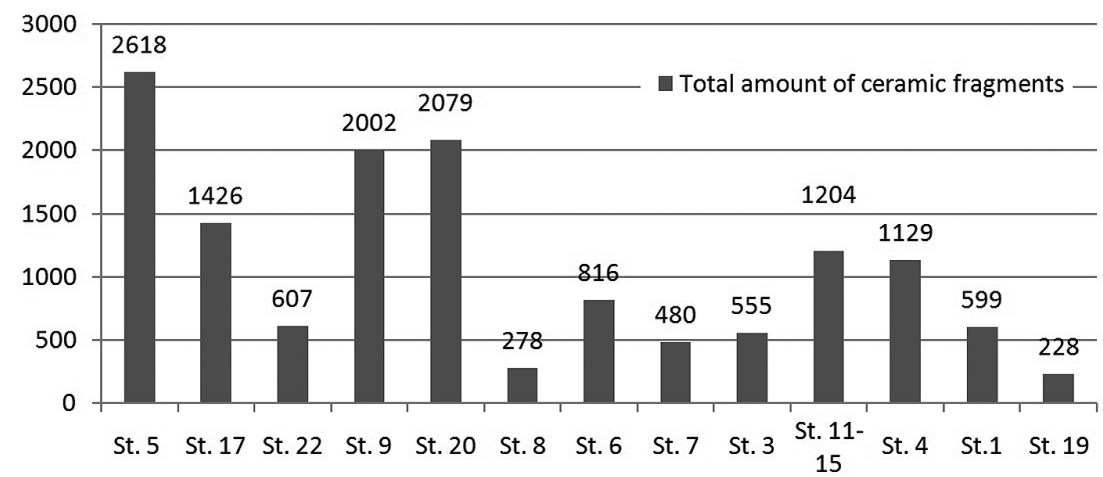

Fig. 3. Zgornje Radvanje. Total amount of ceramic fragments obtained from the settlement structures. 

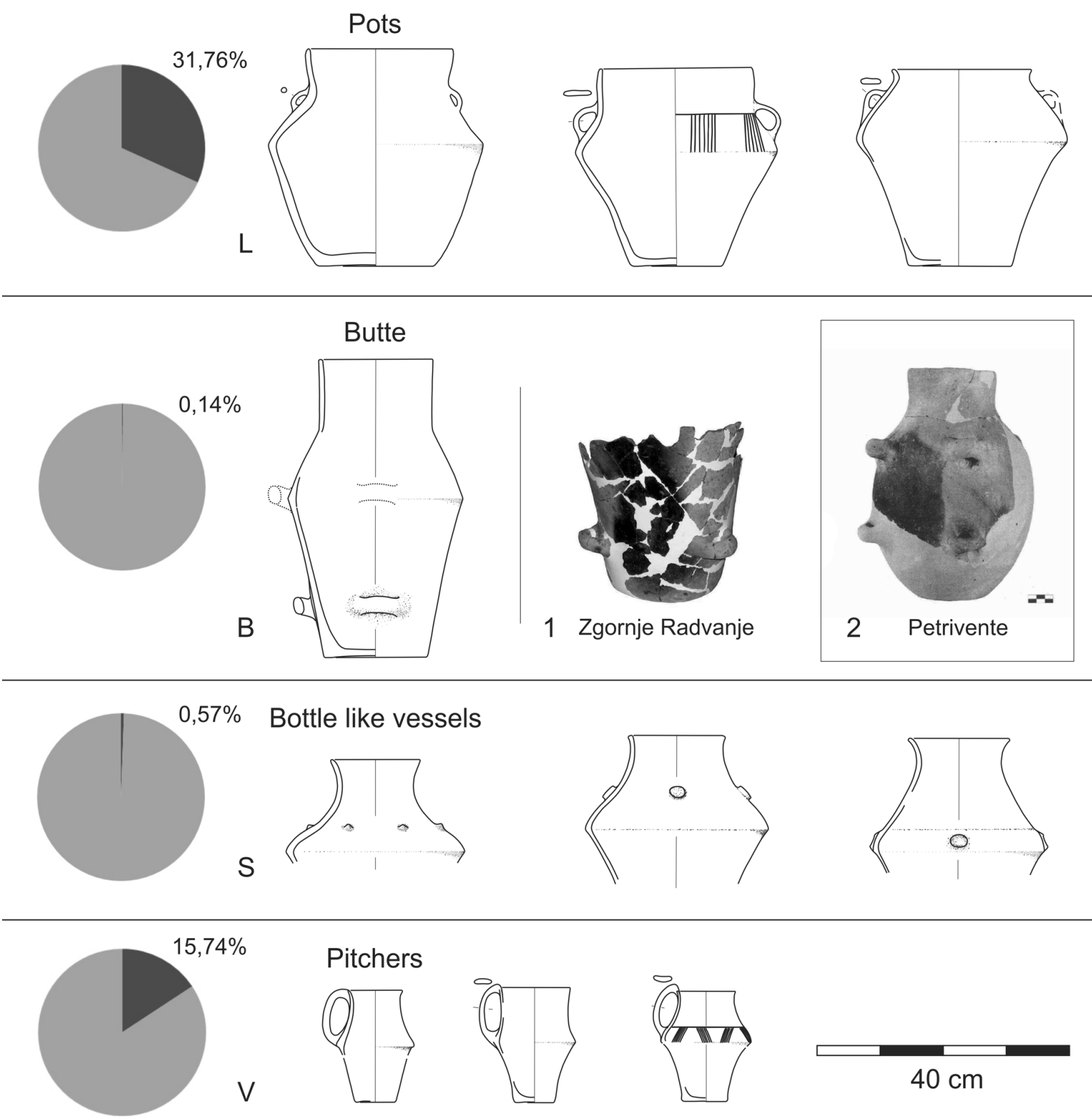

Fig. 4. Pots, a Butte, bottle-like vessels, pitchers and their percentage within the typologically defined finds. Photos of Butte vessels: 1 Zgornje Radvanje, 2 Petrivente (after Kalicz et al. 2007.Fig. 4.14).

4.S; see also Kramberger 2014.Pl. 7.118, Pl. 8.130; 2010.Pl. 3.17, Pl. 9.55). Although they were only partly preserved, it is evident that they occur in two different sizes. While four specimens can be compared with the size and volume of pot group 1, a single bottle-like vessel may match the pots in group 3 in terms of volume. Given the smaller openings and the length and shape of the necks, the bottle-like vessels could have been used to store liquids, but since they are rare, we could expect that vessels or barrels from organic materials were also used for this purpose. According to Prudence M. Rice, vessels used for storing liquid usually have narrow necks to prevent the liquid from spilling and to control pouring, while "a tall, flaring neck acts much like a spout and also serves as a funnel in filling the vessel." Dry material such as grains and seeds are usually stored in wide-necked vessels (see Rice 1987. 241). Nevertheless, at this point, the possibility that pots and bottle like vessels were used also for other purposes cannot be excluded, since ceramic products may serve variety of needs (see Rice 1987.293-301). The biochemical analysis of the organic residues from a contemporaneous site at Ajdovska jama, for example, showed the presence of mid-chain ketones in three pots, which suggests these vessels were used for heating foodstuff. Two of them were larger pots with a relatively small opening, similar to our pots (Šoberl et al. 2014.160, Fig. 5.72AJ, 4AJ; compare with Kramberger 2015.Pl. 9.152). 
A tall vessel with a volume around 13.51 (Apps. $1-2$ ), with horizontal handles on the belly and on the transition to the upper part, for which we use the German name Butte here, because there is no English name for this specific form, has been identified only in a single case (Fig. 4.B). However, the fragments of such vessels are also known from some other locations in Slovenia, 5 and they are a common find at Neolithic and Eneolithic sites in central and south-eastern Europe. In central and south-eastern Europe Butte vessels appear in the Starčevo (e.g., Marić 2013.Fig. 6.7a-b), Körös (e.g., Domboróczki 2010.Fig. 7), Linear Pottery (e.g., Neugebauer, Schöfmann 1981.Fig. 165), early Sopot (e.g., Dimitrijević 1979.275) and early Vinča cultures (e.g., Garašanin 1951.Figs. 17-18). They are also characteristic of Lengyel culture (e.g., Kalicz 1983/1984. Fig. 8.1) and its variant Moravian eastern Austrian group of painted pottery (e.g., Ruttkay 1976.143), of the Bisamberg-Oberpullendorf group (e.g., Stadler, Ruttkay 2007.Pl. 8.11), the Münschöfen culture (e.g., Neumair 1997.Fig. 17), Balaton-Lasinja (e.g., Kalicz 1992.Fig. 7.11), Ludanice (e.g., Pávuk 1981. Fig. 15.16), Jordanów (e.g., Podborský 1970.Fig. 15. 11), and Salcuta cultures (e.g., Sălceanu 2008.Pl. 10.13, Pl.79.1) and also the Late Neolithic period in Greece (e.g., Urem-Kotsou et al. 2002.Fig. 2.5, Fig. 5). Such vessels are mostly undecorated. However, at Early Neolithic Starčevo sites, they appear with barbotine (e.g., Maric 2013.Fig. 6.7a-b), at Linear Pottery sites they are sometimes decorated with incised motifs (e.g., Lenneis 1999.Fig. 4.9-10, Fig. 15. 10; 2010.Fig 4.113), and in the Moravian group of painted pottery, decorated with painted motifs (e.g., Rakovský 1986.Fig. 4.6).

Firstly, it is important to note that the Butte vessel from Zgornje Radvanje was secondarily burnt and that the traces of secondary burning are preserved in a regular vertical line between the handles (Fig. 4.1). The comparison of this phenomena is documented for the further example of such vessel from Petrivente in Hungary (Fig. 4.2), which was attributed to the Sopot culture (Kalicz et al. 2007.3336); the possible explanation could be that the vessels were tied with a rope to a wooden construction (perhaps to the wall of the house) which burnt down. ${ }^{6}$ The reason for tying the vessel to the wall
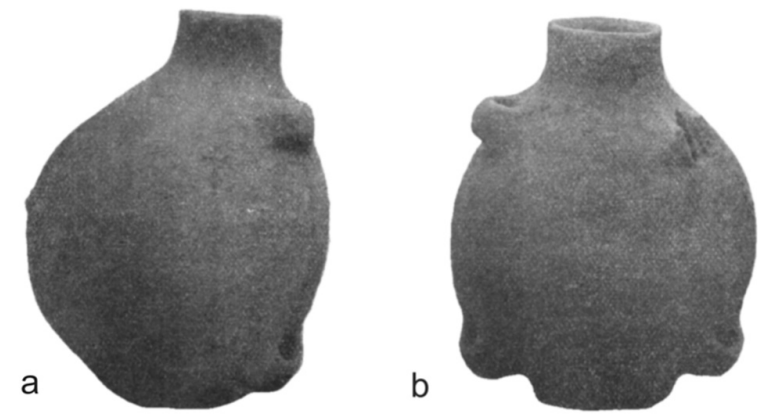

Fig. 5. The irregularly shaped Butte from Hungary: $a$ - side view; $b$ - front view (after Nagy Gyula 1911. Fig. F/a).

of the house could have been to protect food or liquid from ants, rats and other pests; another possible explanation is better access to the content (like water).

Secondly, it has to be mentioned that the forms of Butte vessels are sometimes very irregular. For example, the vessel from Hungary published by Kisléghi Nagy Gyula in 1911 is clearly flattened between the handles (1911.Fig. F/a; Fig. 5). Further examples of significant irregular form come from Bisamberg (Ruttkay 1974/1975.Pl. 10.3; Bisamberg-Oberpullendorf group) and Falkenstein-Schanzboden (Stadler, Ruttkay 2007.Pl. 4.13; Moravian east Austrian group of painted pottery), both located in Austria. In my opinion, the flattened body between the handles could make the vessel from Hungary more appropriate for carrying it on the back - probably to carry liquid, given its shape. This is further supported by the chemical analysis (GC-MS) of a black substance preserved on the bottom of a four-handled Butte vessel from the Neolithic site at Makriyalos in northern Greece. The analysis showed that the black substance is birch bark tar, which was probably used to seal the vessel's surface (Urem-Kotsou et al. 2002. 114). A variety of post-firing treatments are used by potters in different societies to reduce permeability and make the vessels more suitable for holding liquids (see Rice 1987.163).

Carrying loads over long distances is still a regular activity in many societies in the developing world; there are two common ways of loading the burden: head-loading and back-loading (see, for example, Lloyd et al. 2010.1). In rural Africa, for example, car-

5 They were found at Late Neolithic sites at Andrenci (Pahič 1976.Pl. 4.57, Pl. 7.100, Pl. 8.115), Bukovnica (Šavel 1992.60) and Čatež-Sredno polje (Tomaž 2010.91), at the Neo-Eneolithic site at Ptujski grad (Korošec 1951.119, Fig. 55), and at Early Eneolithic sites, such as Pri Muri pri Lendavi (Šavel, Sankovič 2011.find no. 25), Turnišče (Tomaž 2012.finds nos. 116, 190, 575), Gorice pri Turnišču (Plestenjak 2010.find no. 11) and Šafarsko (Šavel 1994.Pl. 12.1).

6 For example, in the Hessisches Landesmuseum, Raetzel Fabian presented a reconstruction which showed Butte vessels hanging on the wall of a Neolithic house (1988.Fig. 93). 
rying water is an important daily activity of women and girls (Fahy Bryceson, Howe 1993.1718-1719). Traditionally, this is done with water jars made of ceramic (Fig. 6). According to Rice, pottery is in principle likely to be preferred only for carrying liquids, because it is very suitable for holding them; for dry goods, baskets have the advantage of being robust and light (Rice 1987.208-209).

Pitchers comprise the remaining type of vessel in the group of vessels with necks and an opening that is smaller than $80 \%$ (Fig. 4.V; see also Kramberger 2014.Pl. 7.116, 121, Pl. 8.127-129, 135-136, Pl. 9.144, 149; 2010.Pl. 7.41-45). They are fairly common in the pottery assemblage (15.74\%), with a shape similar to the bottle-like vessels, but significantly smaller: two reconstructed vessels have volumes around 0.41, while another two objects around 0.21 (Apps. 1-2). 7 They also have only one handle, so it seems reasonable to assume that they were used for drinking.

The group of vessels without necks is comprised of dishes, bowls and pedestal dishes, with openings bigger than $85 \%$ of the maximum body diameter. All types are relatively frequent: $5.6 \%$ of the fragments from the total amount are of bowls (Fig. 7.C; see also Kramberger 2014.Pl. 8.126, Pl. 9.148; 2010. Pl. 1.3-4, 6-7, Pl. 4.23, Pl. 5.27, 30-31), 8.99\% of dishes (Fig. 7.E; see also Kramberger 2014.Pl. 7.111, 113, 115, Pl. 9.143, 145; 2010.Pl. 1.8., Pl. $6.34,39), 11.1 \%$ of dishes or bowls and $14.7 \%$ of pedestal dishes (Fig. 7.En; see also Kramberger 2014. Pl. 7.109, 112, Pl. 8.124, Pl. 9.142, Pl. 9.147; 2010. Pl. 5.25, 28, Pl. 6.33, 37). Bowls and dishes differ only in the proportion between the opening and the height of the vessel. 8 Both forms can occur with handles, grips, appliqués and relatively often also with spouts. On the other hand, pedestal dishes, besides the feet, have characteristic tongue-like appliqués attached to the body.

The dishes, bowls and pedestal dishes found in the studied structures are characterised by inverted or straight lips; different variants are exceptional (see Kramberger 2014.Pl. 5.24). The volumes of reconstructed dishes range from 1.2 to 6.8 litres, but no

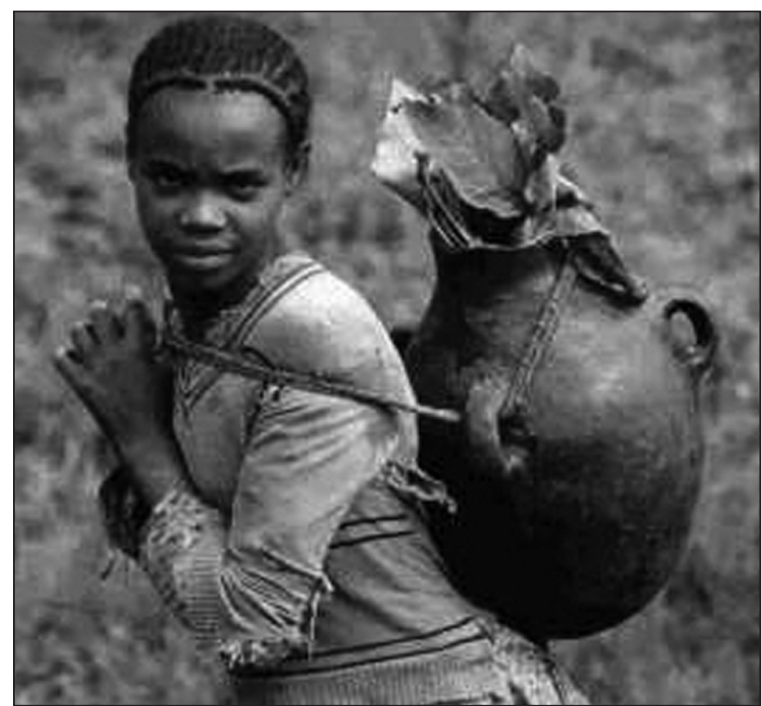

Fig. 6. Ethiopia. Woman transporting water in a water jar (www.unesco.org/water/wwap, 12, photo M. Marzot).

clear groups can be discerned on the basis of capacity. On the other hand, three different groups of bowls can be identified: the first consists of vessels with volumes from 7.4 to 11.1 litres, the second with volumes between 4.1 and 4.4 litres, and the third with volumes between 0.4 and 0.9 litres. The capacity of pedestal dishes was relatively standardised, and their volumes range between 1.5 and 2.5 litres (Apps. 1-2).

The size of the better preserved examples, the relative size of orifices and their percentages in the ceramic assemblage, suggest that some dishes, bowls and pedestal were used for serving food, but the size of openings suggest they were also appropriate for cooking. These suggestions are also supported by the results of researchers in Northern America. A functional study of the Coweeta Creek pottery assemblage in North Carolina, for example, showed that one vessel of a specific type of carinated bowl (i.e. with an inverted lip) 9 has a circular zone of pit marks on the base and lower wall of the interior. Elsewhere, the surface was intact, and according to the authors, it is therefore probable that the pit marks are the result of the bowl's contents being scooped out with a ladle (see Wilson, Rodning 2002. 33, Fig. 10b). Moreover, similar patterns of use of

7 It is important to note that there is also a larger group of pitchers with volumes which, judging from the upper parts, were significantly bigger, but unfortunately not easy to define precisely.

8 The diameter of openings of bowls, according to our criteria, is equal to between 1 to 2 times of their height, while the diameter of openings of dishes and pedestal dishes is equal to between 2-4 times of their height.

9 In this paper, 'lip' refers to a segment located between the body and opening in the case of dishes, bowls and pedestal dishes. Such bowls/dishes are sometimes also referred to as carinated (Wilson, Rodning 2002.33) or restricted (Mlekuž et al. 2013. 134-136). 

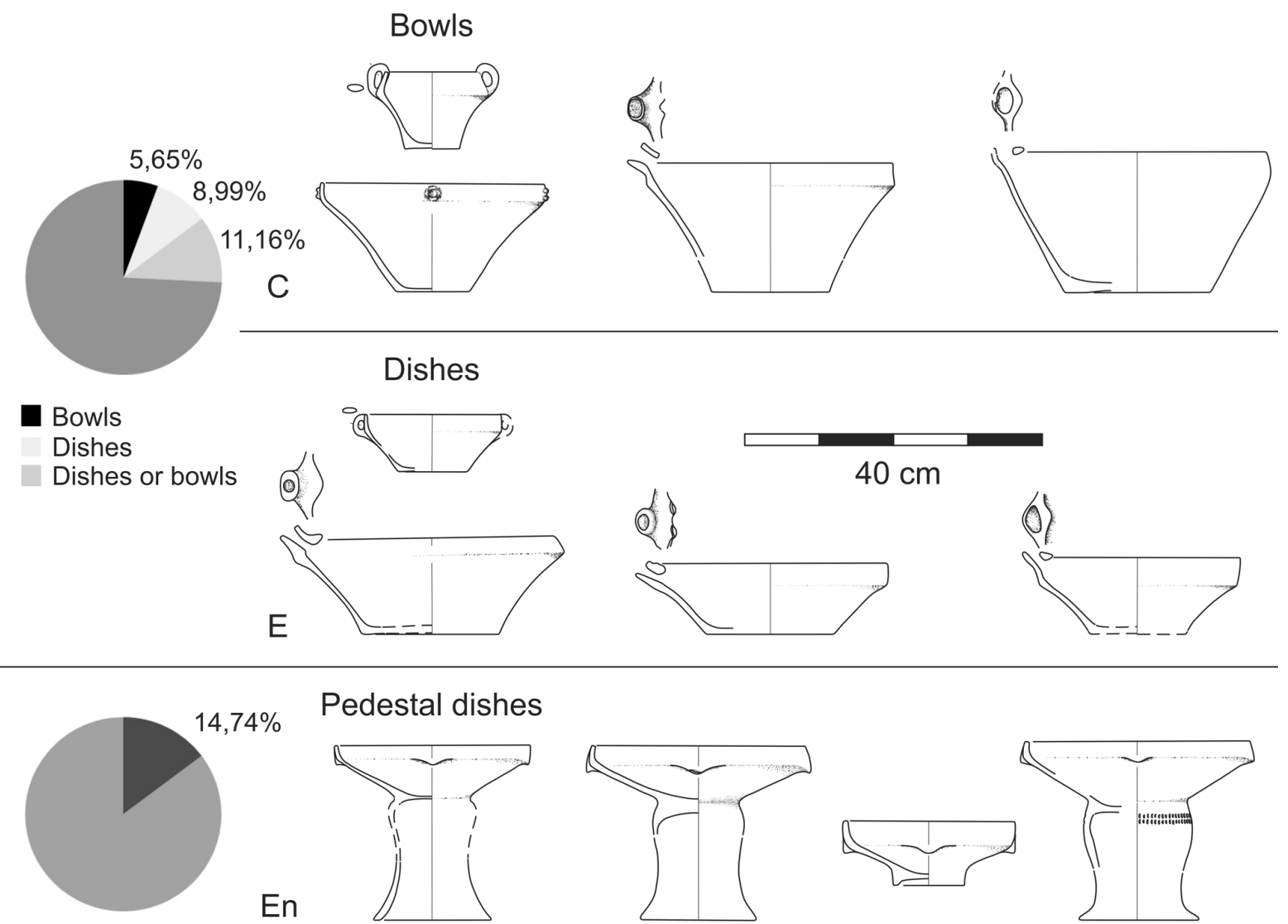

Pedestal dishes

En
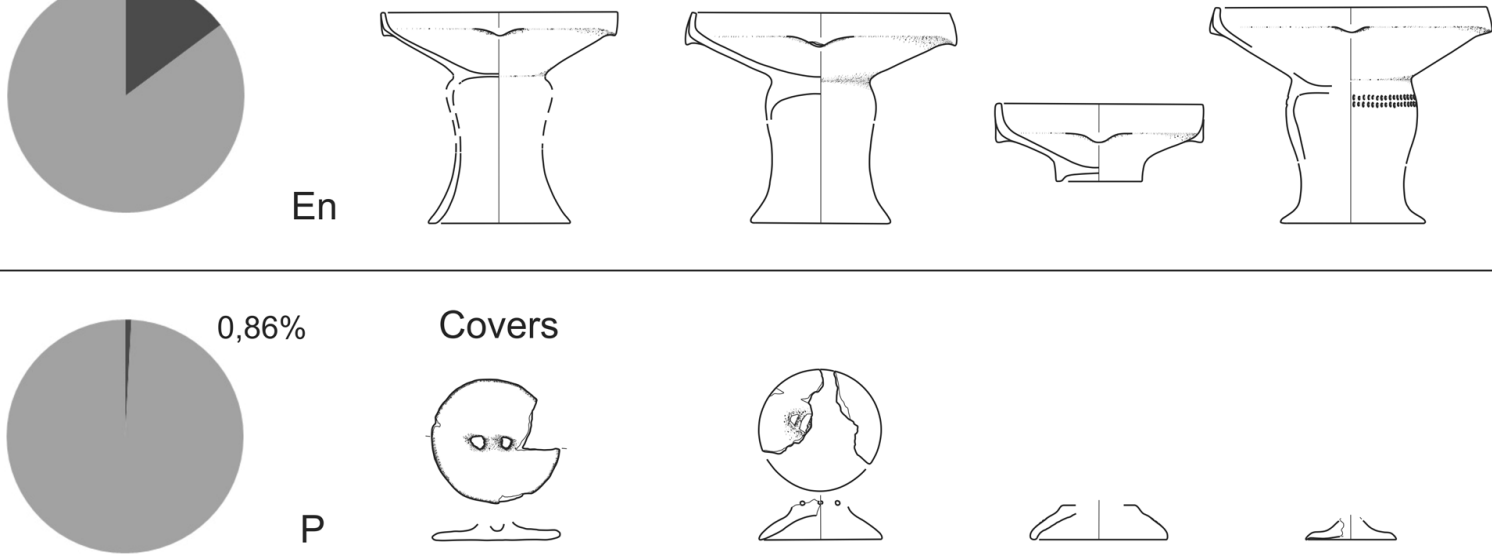

Fig. 7. Bowls, dishes, pedestal dishes, covers and their percentages within the typologically defined finds.

carinated bowls were also recognised by researchers of Lamar-period carinated bowls in Northern Georgia (Hally 1983a; Shapiro 1984) and, consequently, such bowls are interpreted as communal serving vessels (Hally 1983a; 1983b; 1986; Henrickson, McDonald 1983; Wilson 1999; Boudreaux III 2010.2122). However, another similar bowl from Coweeta Creek had a two-centimetre-wide ring of soot encircling the vessel's base indicating that it was placed over a low fire, which could mean that it was used for both cooking and serving (see Wilson, Rodning 2002.33, Fig. 10c).

To come back on the ceramic assemblage from Zgornje Radvanje, the last ceramic objects that are probably associated with the storage, preparation, relocation, and probably food consumption are the ladles
(Fig. 8.Z), covers (Fig. 7.P) and small vessels with massive walls, named as mortars (Fig. 8.MO). Ladles were more common $(4,4 \%)$ than mortars $(0.6 \%)$ and covers $(0,8 \%) .10$ It can be assumed that the larger ladles, which have volumes around 0.1 litres (Apps. 1-2) were used for transferring food, and smaller ones for eating, perhaps. Small ceramic vessels with massive walls could have been used for grinding. In addition to finds which may have been associated with the food-related activities, small vessel that mimic the shape of the larger ones (Fig. 8.M), a special find that, given the traces of secondary burning and biochemical studies of visible organic residues, can interpreted as a lamp (Fig. 8.0; Kramberger 2015), spindles (Fig. 8.Ua), weaving weights (Fig. 8. Ub) and seals (Fig. 8.D) also appeared in the settlement structures.

10 Based on the small amount of the ceramic covers, we could therefore also expect covers from organic materials. 


\section{Techno-functional analysis of pottery}

Clearly, it is not only the form that determines vessels' suitability for particular uses. The use of different clays and tempers for different function classes is widely known ethnographically (Rice 1987.113$167)$ and is also likely to be characteristic of prehistoric societies since the Neolithic period (Borow$s k i$ et al. 2015). Furthermore, types of surface treatments and firing may affect the particular task for which a vessel is used (Rice 1987.226-227; Horejs 2010.18; Lis 2010.239). In the framework of our discussion of the function of individual pottery types in daily food and drink-related practices, we therefore compared their manufacturing technology by looking at the characteristics: the granularity of fabrics, surface treatment techniques and firing atmosphere.

The manufacturing technology is described with macroscopic standards (after Horvat 1999). Dishes and bowls were treated together, because we could not say to which type many pieces belong and because the analysis has shown that there are no significant differences in the manufacturing technology between both types (Fig. 7.C-E). Furthermore, since there is only one example, the Butte was not included (Fig.

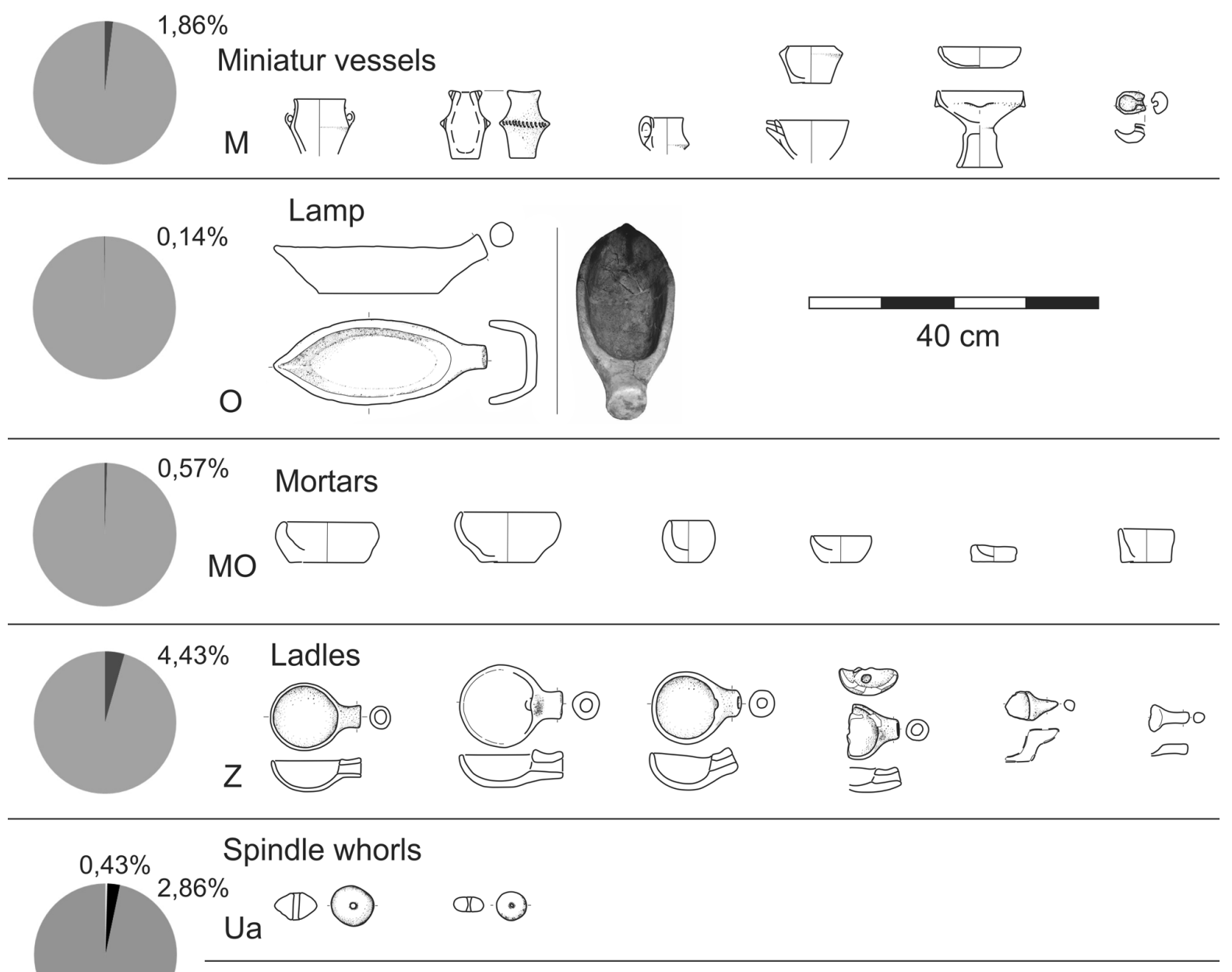

\section{Weaving weights}

Spindle wh.

Weaving we.
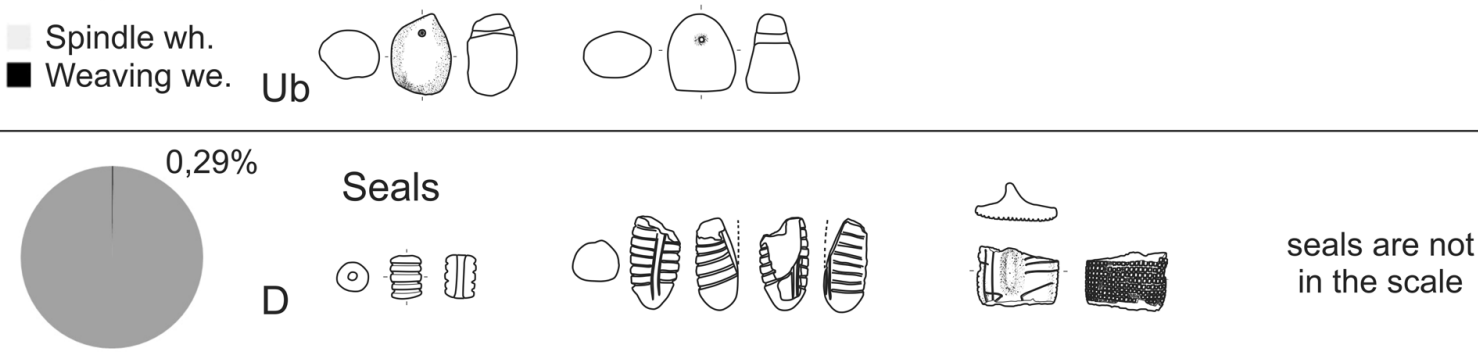

Fig. 8. Miniature vessels, a lamp, mortars, spoons, spindle whorls, weaving weights, seals and their percentages within the typologically defined finds. 


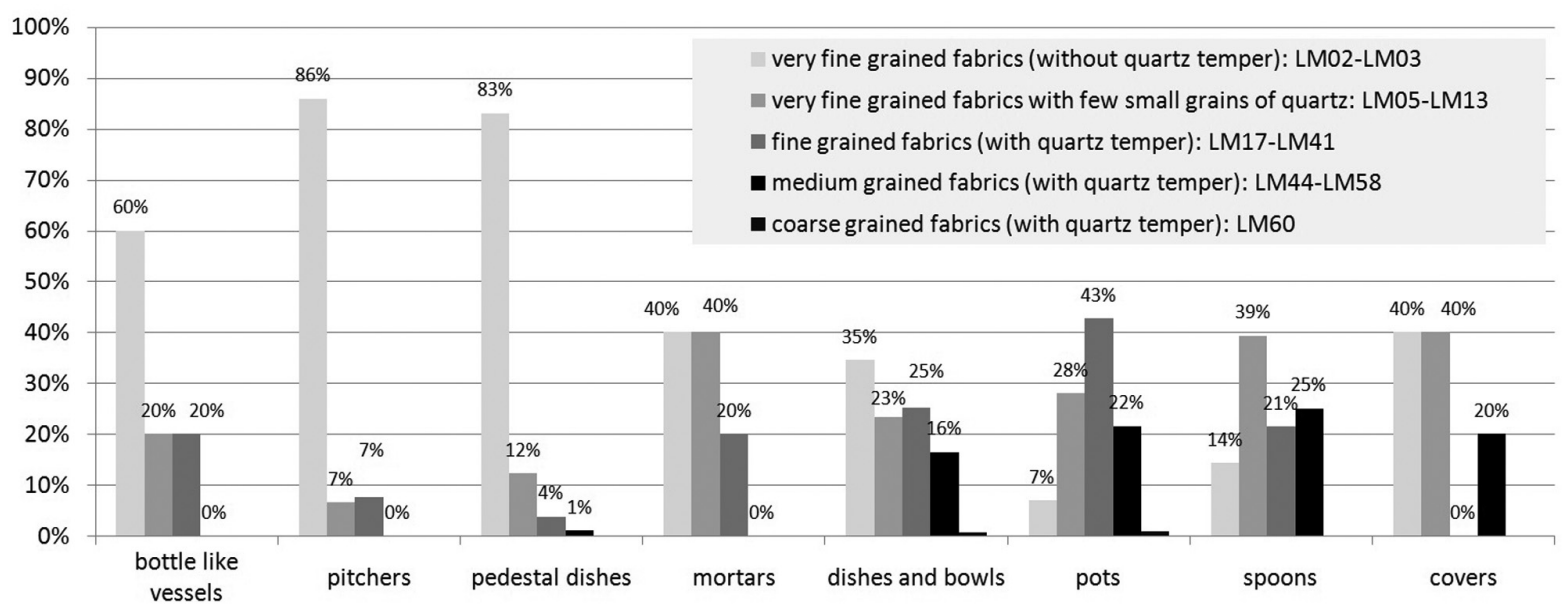

Fig. 9. Granularity of fabrics by vessel type.

4.B), and the data on bottle-like vessels (Fig. 4.S), mortars (Fig. 8.MO) and covers (Fig. 7.P) needs to be treated with caution, since there are only a few examples. 11

The fabrics that were used for pottery production in Zgornje Radvanje contained quartz, mica and iron oxides, while whitish undefined grains and partially burnt organic material were found in only a few items (Kramberger 2014.245, App. 1). Mica, iron oxides, quartz and organic material (impurities) are common inclusions in ceramic bodies in the region and beyond; but there are differences in the sizes of grains and their frequency, especially of quartz. The comparison of the granularity showed that in most cases bottle-like vessels (60\%), pitchers (86\%) and pedestal dishes $(83 \%)$ were made of the most fine-grained fabrics. On the other hand, bowls, dishes, pots, ceramic ladles, lids and mortars were often made of more granular fabrics with more quartz (Fig. 9).
Most often the surfaces of all types of vessel are matt and smooth, which means that these vessels were sponged before firing to remove irregularities from the surface. This was carefully done, perhaps when the surface was still wet, because there are usually no traces of a tool or hand. Only a smaller number of vessels appear with different surface treatment. The surface of mortars (33\%), pots (6\%), spoons $(12 \%)$ and covers $(17 \%)$ was sometimes partly uneven and rough, so it was probably smoothened before firing. Dishes, bowls (both together in $2 \%$ ) and pedestal dishes $(2 \%)$ rarely appear with this type of surface, while other types were not treated in this way at all. On the other hand, in some cases, the surfaces of pitchers (16\%) and pedestal dishes (10\%) were partly or completely polished. This was probably done with a soft object when the surface was leather-hard, and the result is a completely smooth and shiny surface. Vessels with this surface are also present among dishes, bowls (3\%) and pots (1\%),

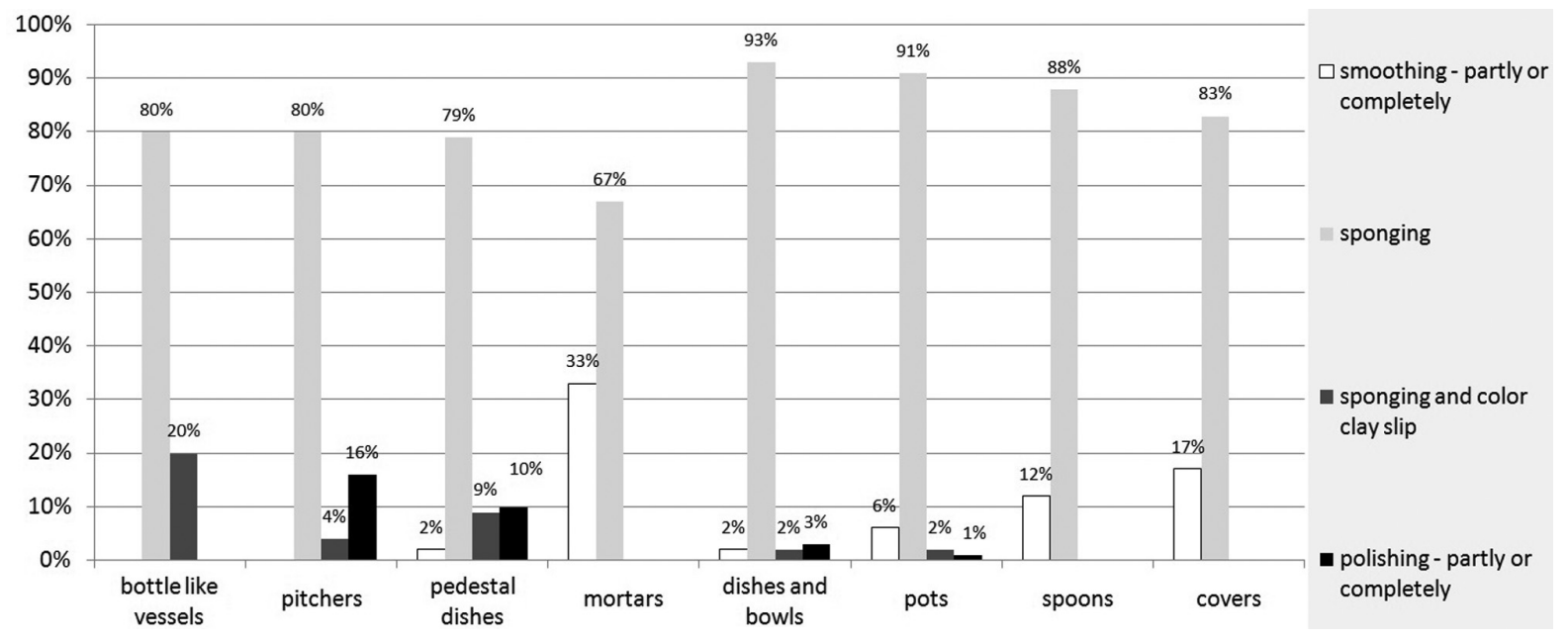

Fig. 10. Surface (finishing) treatment techniques by vessel type.

11 There are only five examples of bottle like vessels, four mortars - one of them without original surface - and six covers. 
but relatively less often. Moreover, in comparison to dishes, bowls and pots, the surfaces of pedestal dishes $(9 \%)$, pitchers (4\%) and bottle-like vessels (1 example, $20 \%$ in total) were more often treated with sponging and a colour clay slip, while mortars, spoons and covers do not appear with a slip at all (Fig. $10)$.

The firing atmosphere differs from vessel to vessel, whereby we may divide firing conditions into two main groups: types of conditions which result in a greyish/dark greyish surface and firing conditions which result in a bright coloured surface. A comparison of both groups of firing conditions within different pottery types showed that the bottle-like vessels $(60 \%)$, pitchers $(85 \%)$ and pedestal dishes $(60 \%)$ were mostly burned in incomplete oxidizing or oxidizing conditions with a reducing atmosphere at the end. Consequently, the surface of these vessels is often greyish/dark grey. In contrast, in most cases, dishes and bowls (71\%), pots (94\%), ceramic ladles (83\%), lids (92\%) and mortars (100\%) were fired in incomplete oxidizing or oxidizing conditions, so the surfaces are brightly coloured (Fig. 11).

Finally, the differences in the granularity, surface treatment techniques and firing atmosphere are further indices that different vessel types served different purposes. According to Rice, the amount, size and shape of inclusions in fabrics influence porosity and density and, therefore, a vessel's suitability for holding liquids (Rice 1987.231). This means that vessels made of less granular fabrics (in our case, bottle-like vessels, pitchers and pedestal dishes) may have been more appropriate for this particular purpose. Different surface treatment techniques (burnishing, sponging, polishing, clay slip) can also reduce the penetration of moisture into a vessel (Ibid. 231).
Moreover, besides clear visual differences between vessels that were fired in an oxidising/incomplete oxidizing atmosphere with a reducing atmosphere at the end and vessels fired in incomplete oxidizing or oxidizing conditions, there might be a similar reason for using both methods, since, according to Rice, charred organic material remaining in the walls may reduce porosity (Ibid. 231-232).

\section{Opening diameters and function of dishes, bowls and pedestal dishes}

As mentioned above, according to their shape some dishes, bowls and pedestal were perhaps used to serve meals. In our opinion, this is more likely, especially in the case of pedestal dishes, since the technical/functional analysis showed they are similar to pitchers: both types are usually made of very finegrained fabrics, surfaces were treated with sponging, polishing or clay slip and were mostly fired in incomplete/complete oxidizing conditions with a reducing phase at the end of firing. Biochemical investigations of ceramic assemblage from the Neo/Eneolithic site Moverna vas showed that pedestal dishes have the highest preserved lipid concentrations of all the vessel types, even higher than pots and small cups, which means that they were probably used in food-related practices over an extended period $\left(\check{S}_{0}\right.$ berl et al. 2014.163-164, Fig. 13). Furthermore, beside pots, the pedestal dishes in Moverna vas proved to be unique vessel types associated with birch-bark tar (Ibid. 164). Birch-bark tar can be used for many purposes, including as already mentioned, to seal the vessel's surface (Ibid. 164; see also Urem-Kotsou et al. 2002.114).

Based on the foregoing, and if we accept the hypothesis that pedestal dishes could have been used to

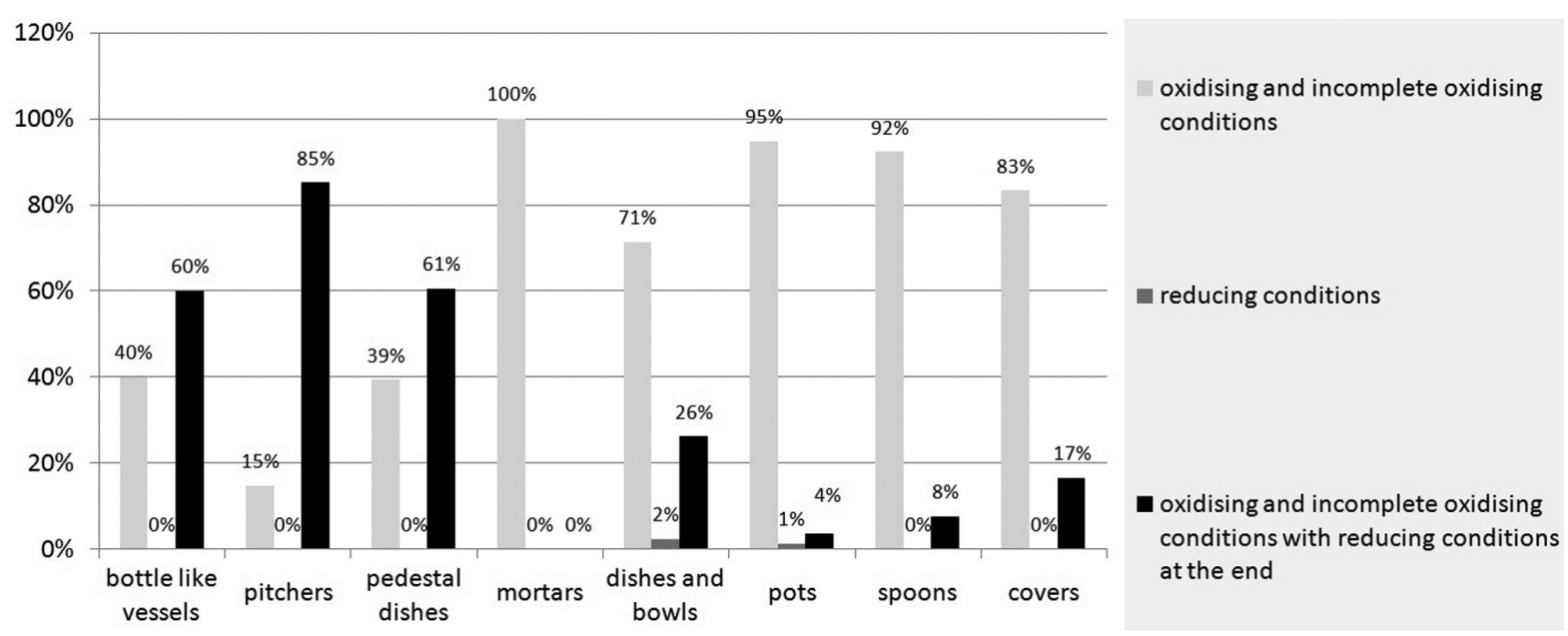

Fig. 11. Firing atmospheres by vessel type. 


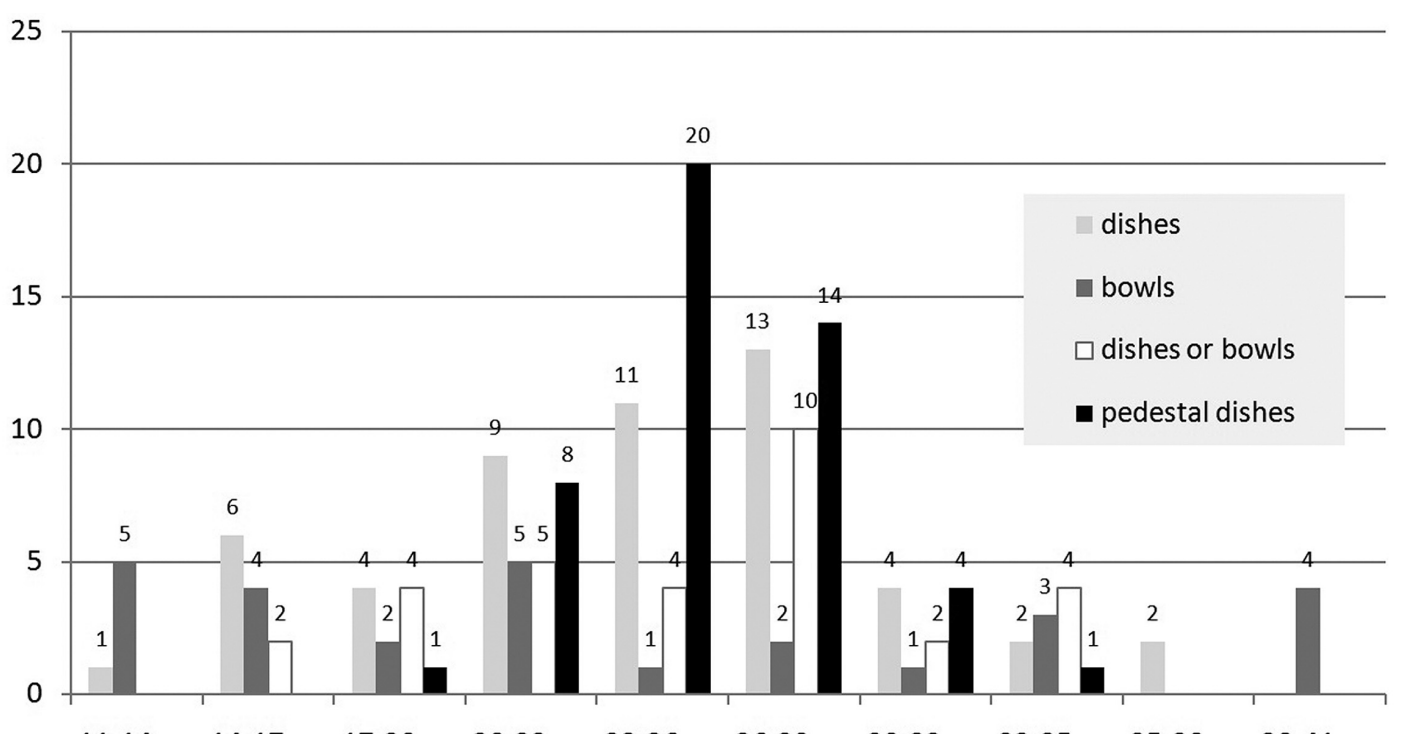

$11-14 \mathrm{~cm} 14-17 \mathrm{~cm} \quad 17-20 \mathrm{~cm} \quad 20-23 \mathrm{~cm} \quad 23-26 \mathrm{~cm} \quad 26-29 \mathrm{~cm} \quad 29-32 \mathrm{~cm} \quad 32-35 \mathrm{~cm} \quad 35-38 \mathrm{~cm} 38-41 \mathrm{~cm}$

Fig. 12. Opening diameters of pedestal dishes, dishes and bowls showing size classes.

serve meals, the question arises as to how precisely food consumption could have been carried out? In order to try to understand the dining habits at the site, a statistical comparison of the size of openings of dishes, bowls and pedestal dishes was planned. For this purpose, all 153 ceramic objects pertaining to these vessels from structures $5,17,22,9,20,8$, $6,7,3,11-15,4,1$ and 19 were selected; 52 examples were from dishes, 27 from bowls, 31 from dishes or bowls and 48 from pedestal dishes.

The analysis revealed that only one smaller group of vessels have openings between 11 and $20 \mathrm{~cm}$; most these are dishes and bowls (30); only one pedestal dish has an opening diameter of around $19 \mathrm{~cm}$ (see Kramberger 2014.Pl. 9.147). The reconstructed vessels which fall into this category have volumes between 0.4 and 0.9 litres, which could mean that they were appropriate for individual food consumption (Apps. 1-2). On the other hand, a large quantity of bowls and dishes have larger dimensions and so could not be used for individual consumption. The size of openings of such pedestal dishes, bowls and dishes is most often between 20 and $29 \mathrm{~cm}$ (59 dishes and bowls; 42 pedestal dishes), some are even bigger, and the biggest bowls and dishes may have openings between 35 and $41 \mathrm{~cm}$ (Fig. 12)). Taking into consideration completely reconstructed vessels, such bowls range in volume from 4.1 to 11.1 litres, dishes between 1.2 and 6.8 litres, and pedestal dishes between 1.5 and 2.5 litres (Apps. 1-2).

It is of course likely that vessels made from wood and other organic materials were also used in foodrelated practices, and therefore they could also have been used for serving meals at the site, but they do not appear in our statistics, since wooden objects have not survived. However, there is some possibility that the lack of vessels with smaller diameters on the one hand, and a larger amount with larger diameters on the other, to some extent indicate dining habits.

From ethnographic studies in Slovenia it is well known that even in the recent past families often ate meals from one vessel. According to Gorazd Makarovič, for example, eating meals from one dish was very common in Slovenian territory until the end of the $19^{\text {th }}$ century and still often during the period between the two world wars (Makarovic 19881990.170). According to Meta Sterle, dishes used for group dining had a special name, 'čpine' (Sterle 1987.

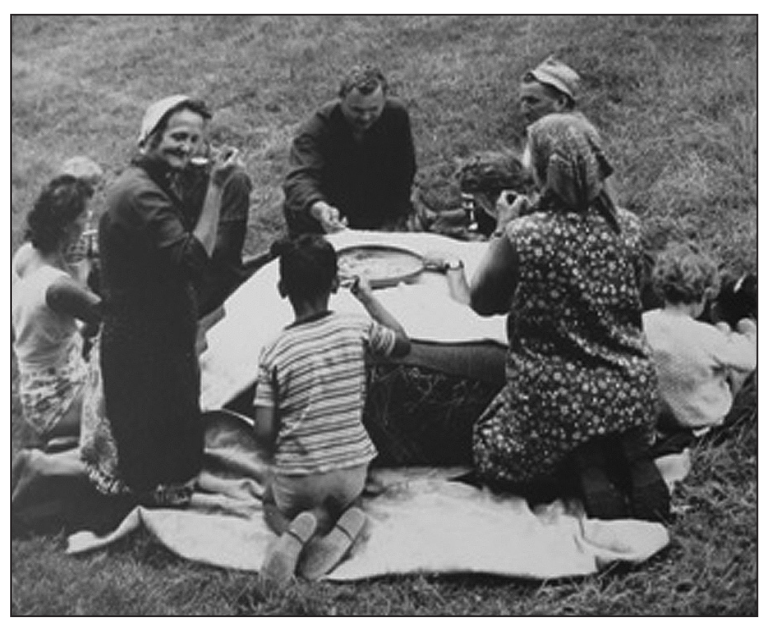

Fig. 13. At lunch in the Poljana meadows near Korensko sedlo (Slovenia), mid-20th century (from photo library of Gorenjski muzej). 
110). Only wooden spoons were widespread cutlery items, but were also not always used; many meals were eaten only with the hands. According to written sources, paintings and photographs, people from different regions of Slovenia - Prekmurje, Bela Krajina, Dolenjska and Gorenjska - ate from one large dish. Even the size and shape of preserved dishes from the 19 $19^{\text {th }}$ century testify to the fact that they were intended for eating meals by a group of people; they are relatively big, usually with slightly inverted rims on which a spoon can be rubbed (Makarovic 1988-1990.169-172). As mentioned above, researchers in Northern America identified traces of spoon-scratches on bowls with inverted rims, indicating that this shape was well suited to spooning out food. It is perhaps for a similar reason that bowls, dishes and pedestal dishes from the studied site have slightly inverted lips. ${ }^{12}$ Moreover, restricted bowls and dishes are also ideal as serving vessels because their slightly inward sloping walls are advantageous for containing contents during serving.

According to Irena Keršič, even chairs were rare in the Slovenian peasant homes in the $19^{\text {th }}$ century in some regions (Keršič 1988-1990.353); only individual farmers had tables (Ibid. 354). Various objects could be used to serve food; in some cases, they used so-called 'menterge' that were otherwise used for mixing bread. Elsewhere, they may also have used shelves above the hearths and benches without backrests, which normally served for placing water vessels, or benches along the wall of the house, as well as hearths and ovens (Keršič 1988-1990.352-358). While dinning during traditional hand haymaking, for example, a group of people may have used only a bundle of dried grass for easier access to the food (Fig. 13). This particular purpose may have been served pedestals on pedestal dishes, and it is possible to imagine a similar type of food consumption at the studied site and during prehistoric periods in general.

\section{Carbonized organic residues and traces of se- condary burning}

\footnotetext{
"Vessel shape, size and manufacturing technology give archaeologists an indirect basis for hypotheses about vessel use, or at least suggestions about the functions for which a vessel was particularly well suited" (Rice 1987.232). However, traces of secondary burning and carbonized organic residues,
}

as direct indications of use are also available in our ceramic assemblage. Traces of burning can appear on the interior of vessels, but are more often documented on the exterior; on the other hand, in most cases, visible carbonized organic residues are encrusted on the interior of the walls. This suggests that vessels with both features were used for cooking (e.g., Ashley 2001.136-139; Braun 2010.84-85). However, we may not completely exclude other possibilities, since the vessels could also have been exposed to uncontrolled fire, such as when the house in which a particular vessel was burnt down, as in the case of our Butte from Zgornje Radvanje. Something similar holds for visible carbonized organic residues encrusted on vessel surfaces, because each pattern is more the result of one of the last events, than of multiple cooking episodes (Oudemans, Boon 1993.222; Budja 2014.196), so some specimens may have been subjected to uncontrolled fire.

Based on the above, single cases of vessels with traces of secondary burning and carbonized residues may not allow us to draw a final conclusion in the interpretation of their use. Thus, in the following analysis, we try to test how often traces of secondary burning and carbonised residues are present on the pottery and if these are actually related to particular vessel types. Analyses showed that a special variant of dishes and bowls - dishes and bowls with a spout $(60 \%)$ - most frequently bore traces of secondary burning. Moreover, organic residues are most often preserved on the interior of these vessels (44\%). Carbonized remains (18\%) and traces of secondary burning (6\%) are also sometimes found on dishes and bowls without a (surviving?) spout, while they rarely occur on the other ceramic forms (Fig. 14). According to this, we believe that bowls and dishes with spouts were connected with cooking or heating up food. Similar observations were made, for example, by Dushka Urem-Kotsou, Kostas Kotsakis and Ben Stern while studying the function of Neolithic 'cooking pots' from a Neolithic site at Makriyalos in Northern Greece (Urem-Kotsou et al. 2002. 112-113) and by Keith H. Ashley while making a similar analysis of the San Pedro pottery from a North Beach site on the coast of north-eastern Florida (Ashley 2001.136-139). Moreover, mid-chain ketones, which are used as biomarkers for exposure to high temperature, were observed in bowls and dishes from the partly contemporary site at Moverna vas, showing with a high probability that these vessels were used for cooking (Šoberl et al. 2014.163). Ne-

12 See, for example, Kramberger 2014.Pl. 7.109, 112, Pl. 8.124, Pl. 9.142-143, Pl. 10.155, 159, 161. 


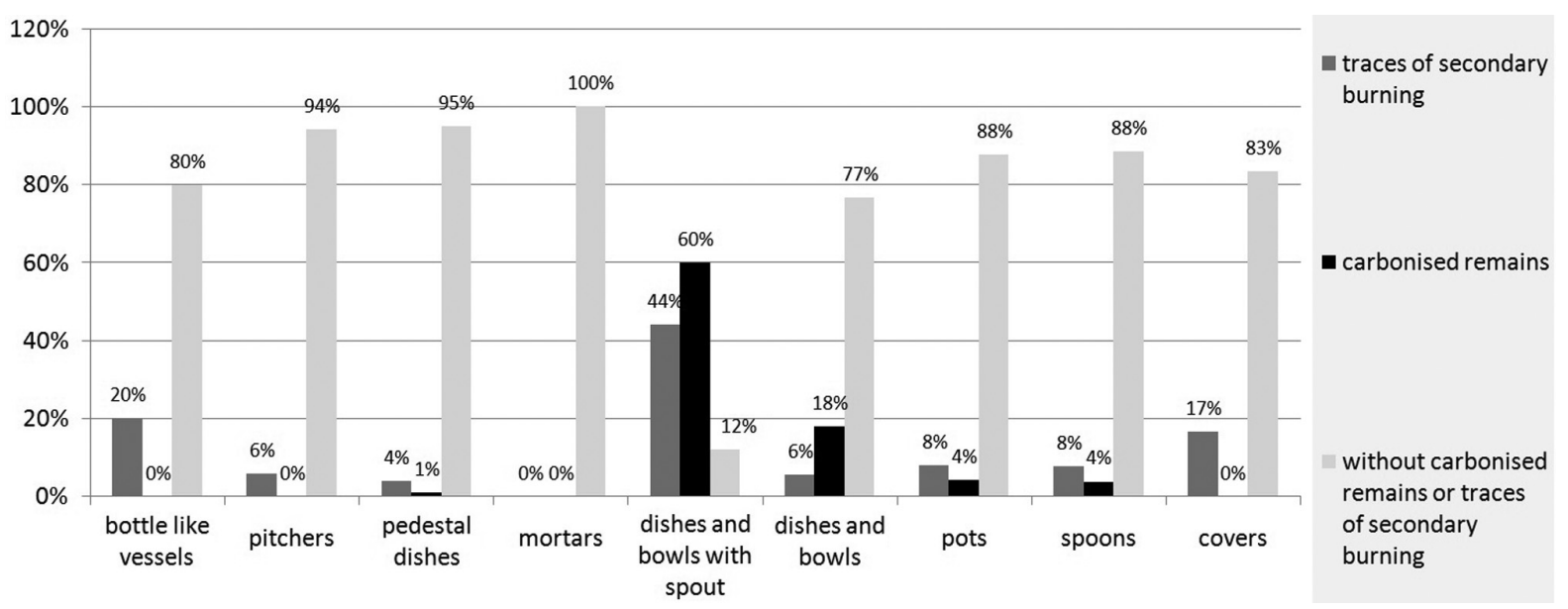

Fig. 14. Traces of secondary burning and carbonized remains by vessel type.

vertheless, at this stage of research, we cannot completely exclude the possibility that the visible black residues preserved on our dishes and bowls are associated with post-firing surface treatment techniques; firstly, because the study is based only on 25 pieces of dishes and bowls with spouts, and secondly, because analyses of other sites have shown that charred organic residues can be either food remains or birch-bark tar (see Šoberl et al. 2014.150-151, 158, Fig. 10).

\section{Settlement structures and the ceramic assem- blages}

The study of the composition of the ceramic assemblages of different types of structures at the settlement of Zgornje Radvanje gives us interesting evidence about the storage, preparation and consumption of food and drink. It was found that the composition of these ceramic assemblages is not homogeneous and that it relates to the type of structure. The first deviation was noted within trapezoidal structure 5. It was found that the smaller pits excavated at the bottom of the feature (structure 5 phase 1) contained more of the larger pots (51.8\%). Most were relatively well preserved, so if it is accepted that larger pots were primarily used for storage, these pits may be interpreted as storage pits (see Kramberger 2010.312, Figs. 2-3, Fig. 23, 13 Apps. $1-2)$. In addition, these pits contained fragments of dishes and bowls (25.9\%), fragments of a pedestal dish (3.7\%) and a single bottle-like vessel (3.7\%). In phase 2 of structure 5 , defined by the remains of a trapezoidal house, pots (27.5\%), dishes, bowls (a combined total of $13.7 \%$ ), pedestal dishes (6.9\%), pitchers (15.6\%) and ladles (3.7\%) are common. A similar composition of the pottery was found in other buildings with a deepened trapezoidal plan and a fireplace or hearth, as well as in both rectangular houses with fireplaces, the only difference being that the latter also contained weaving weights. It is also interesting to note that the only Butte-type vessel was found in structure 20 and that bottle-like vessels were found in other structures with fireplaces: two in structure 5 (the second example is from phase 2), one in structure 17 and one in structure 22 . These are all larger examples of bottle-like vessels found on the settlement; only one small bottlelike vessel has been found (Fig. 15).14

In features without fireplaces, basically the same types of vessels as in buildings with fireplaces were found, with only a few exceptions. The composition of the ceramic finds suggests that the smaller feature (19) was used for weaving, since in addition to the rectangular buildings with a fireplace it is the only other structure in the settlement in which weaving weights were recorded, and even in a large quantity $(37.5 \%$, i.e. at least 12 different objects). The smaller features 4 and 1 differ from the others in containing spindle whorls. However, the remaining features yielded a similar composition of finds as the features with fireplaces or hearths, and the only difference is that they are based on the percentages of different ceramic forms, less standardized. As a result, their purpose is more difficult to interpret on the basis of ceramic finds alone (Fig. 16).

13 The bottle-like vessel was recognised later as a special vessel type, and in the first publication it was treated as a pot; therefore, there is a small difference in the percentages of pots in phase 1 between the former and this publication.

14 This bottle-like vessel is similar in size to some pitchers and also has similar decoration (Kramberger 2014.Pl. 8.130). 


\section{Conclusion}

The Eneolithic settlement at Zgornje Radvanje shows a wide range of vessel types, of which some were related to the storage, preparation and consumption of food and drink, while others were connected with various daily activities such as textile production. Pots and bottle-like vessels were the largest vessels at the settlement. For the biggest pot specimens we can calculate volumes between 12.1 and 15.4 litres, which makes them well suited for storage. Bottle-like vessels could have been used for storing liquids, although we should note that they are rare in the settlement, so we also have to consider the use of barrels or leather bags for storing liquids. The pitchers of different sizes and varying smaller volumes served as drinking vessel.

Techno-functional analyses showed that bottle-like vessels, pitchers and pedestal dishes were often produced to different standards than pots, dishes, bowls, mortars, lids and ladles. The first were in most cases made of the most fine-grained fabrics, fired in incomplete oxidizing or oxidizing conditions with a reducing atmosphere at the end, and their surface before firing was carefully treated (sponging, colour clay slip, polishing). On the other hand bowls and dishes, pots, ceramic ladles, lids and mortars were often made of more granular fabrics with more inclusions of quartz and mostly fired in incomplete oxidizing or oxidizing conditions. Their surface was most often sponged before firing, and they appear with shining polished surfaces and a colour clay slip rarely. The different surface treatments and granularity of fabrics influences the vessels suitability for holding liquids, while the reducing atmosphere at the end of firing process produces the greyish/dark greyish surface. Based on these, we may conclude that one of the most important factors in the production of pitchers, bottle-like vessels and pedestal dishes was to prevent liquids from penetrating the ceramic, and so these vessels were well suited for storing and serving liquids or perhaps a liquid food (pedestal dishes).

Some vessels give further clues as to their use. In this connection, we can mention the dishes and bowls with spouts, which of all vessel types had the most frequent traces of secondary burning, showing that they were associated with the preparation of food, cooking or heating up meals. Preserved carbonized residues appeared most frequently on their inner surfaces, which could be interpreted as food remains. However, such interpretations based solely on visible residues may be misleading, since something that looks at the first sight like food remnants could be something else - for example, the result of a post-firing treatment technique to produce a more liquid-resistant surface. Therefore, some chemical analysis of carbonized residues needs to be done to test our assumption.

Concerning the use of the vessels, especially interesting is the so-called Butte, a vessel type well known in the Neolithic and Early Eneolithic in central and south-eastern Europe, which characteristically have horizontal handles on the belly and either on the transition to the upper part of the body or on the shoulders. On the one hand, the shape of this vessel with a small opening and a voluminous body indi-

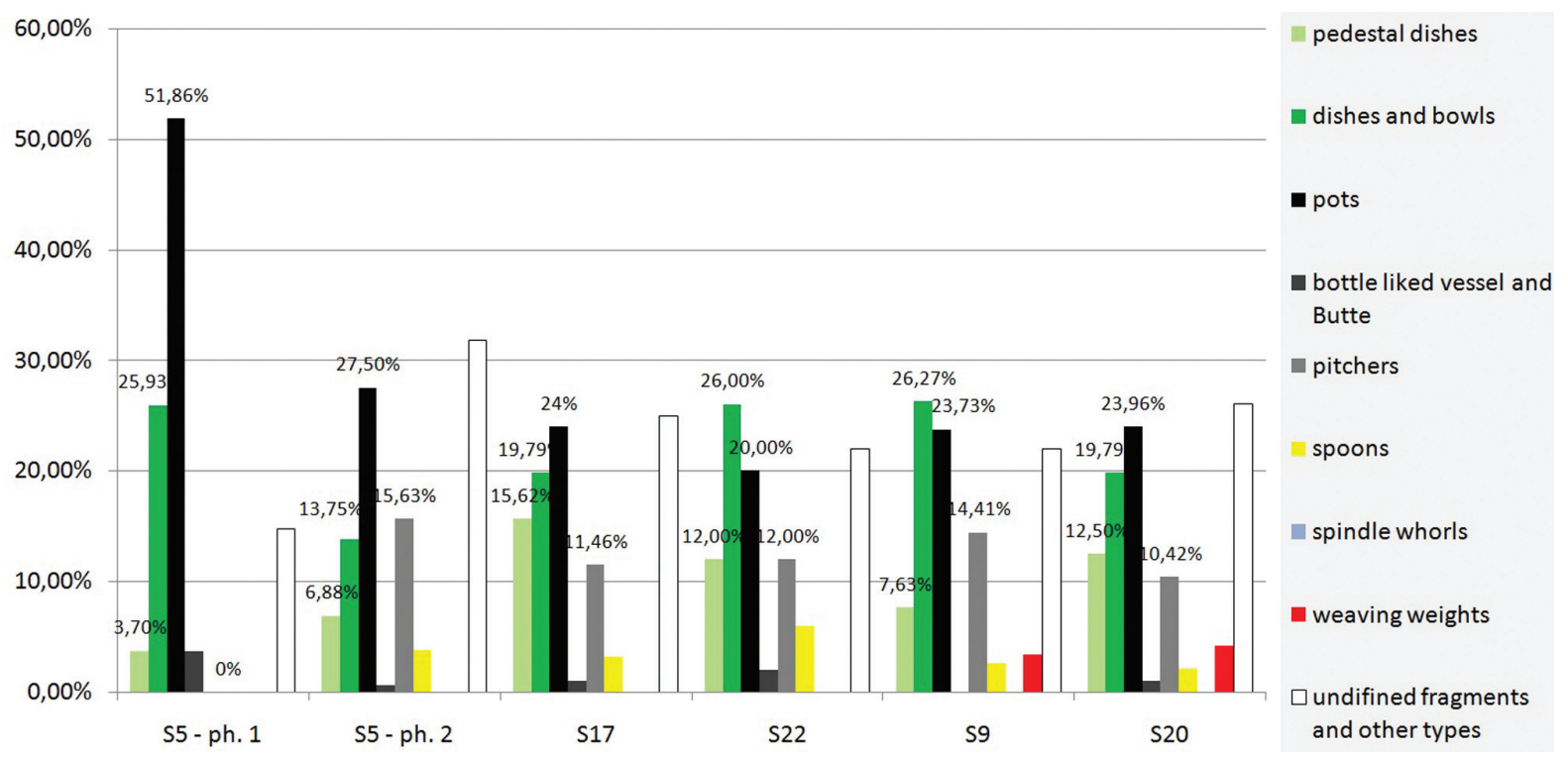

Fig. 15. Structures 5, 17, 22, 9 and 20 (with fireplaces). The composition of pottery assemblages. 


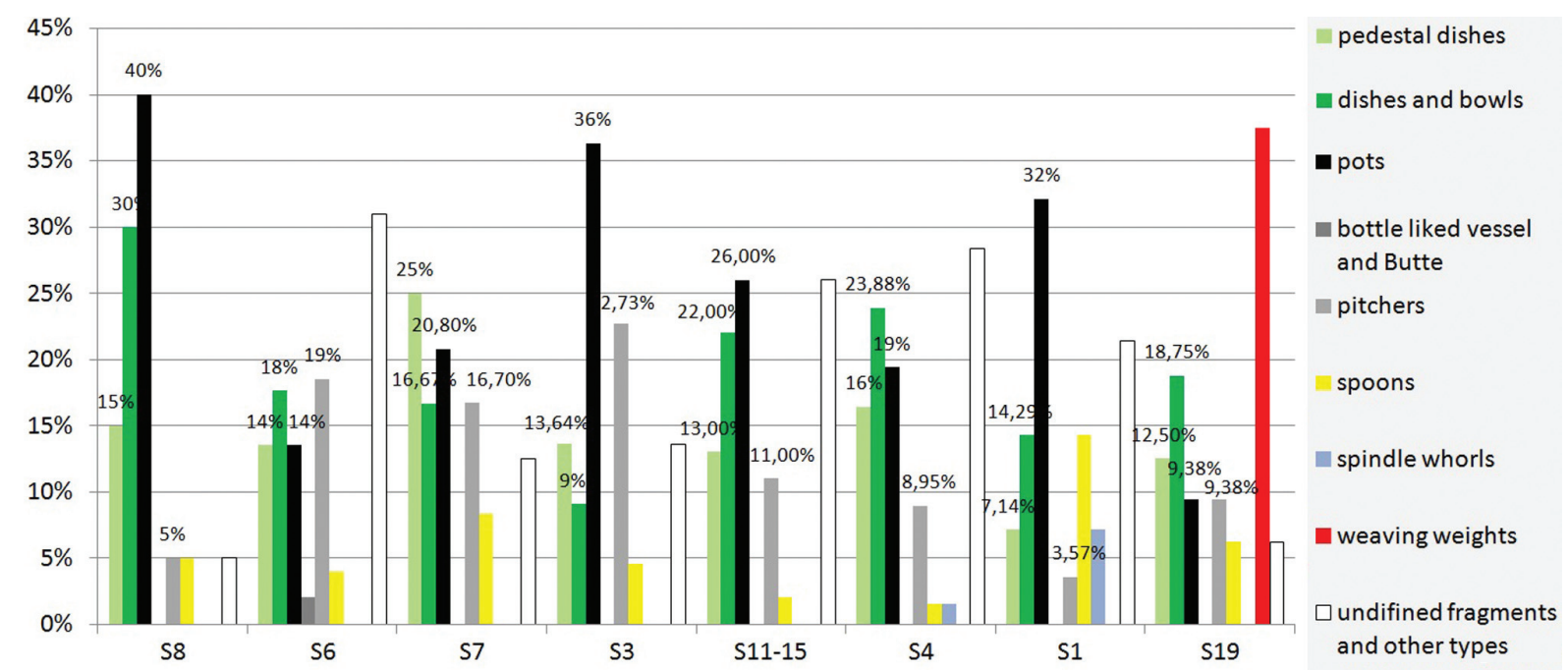

Fig. 16. Structures 8, 6, 7, 3, 11-15, 4, 1 and 19 (without fireplaces). The composition of pottery assemblages.

cates that it was used in connection with the storage of liquids; on the other hand we know from ethnographical parallels, that similar vessels with handles are used as a kind of 'backpack' for transporting water over large distances.

Pedestal dishes and perhaps also dishes and bowls without spouts, may have been used for serving meals. Smaller ladles could be used as a form of cutlery, while bigger ones were suited for transferring food. Most pedestal dishes, dishes and bowls are relatively large, which means that they could contain more food than was needed for one person. Consequently, this could mean that they were intended for more people, which is also known from ethnographic parallels, and on the territory of Slovenia, for example, was still common until the Second World War. Pedestals may have made access to food easier, while the inverted lips of such vessels could have simplified spooning up the food.

Besides the analysis of the form and function of the vessels from Zgornje Radvanje, we also studied the distribution of pottery in different settlement structures. In this connection, it is interesting to mention that this analysis shows indeed some differences be- tween the various settlement structures. We can conclude that the ceramic assemblages which were obtained from the single-roomed trapezoidal houses and double-room rectangular buildings are relatively standardised in their composition. Hearths or fire places were found in these features, so it may be assumed that they served as residences and places where food was prepared. The smaller pits excavated at the bottom of structure 5 served perhaps as storage pits, because larger pots that can be interpreted as storage vessels were predominant in them. It should be mentioned, of course, that structures with fire places also served for other activities, as they contained, among other things, weaving weights, seals and a special find which can be interpreted as a lamp. On the other hand, the ceramic assemblages in other features are less standardised in their composition, so they probably served other purposes; although for most of them it is not yet clear which. To solve this problem, at first the fragmentation of ceramic assemblages and the comparison of stone tool assemblages within the features need to be examined. Almost $500 \mathrm{~kg}$ of stone tools and stone implements were found at the site, and concerning that, the settlement at Zgornje Radvanje diverges significantly from other known Eneolithic sites in Slovenia. 


\section{References}

Arh M. 2012. Neo/Eneolitska naselbina Zgornje Radvanje - Habakuk 2. Unpublished undergraduate thesis. University of Ljubljana. Ljubljana.

Ashley K. H. 2001. Beyond Potsherds: A Technofunctional Analysis of San Pedro Pottery from the North Beach Site (8SJ48). The Florida Anthropologist 54(3-4): 123-149.

Borowski M. P., Furmanek M., Czarniak K. and Gunia P. 2015. Steatite-tempered pottery of the Stroke Ornamented Ware culture from Silesia (SW Poland): a Neolithic innovation in ceramic technology. Journal of Archaeological Science 57: 207-222.

Boudreaux III E. A. 2010. A Functional Analysis of Mississippian Ceramic Vessels from Town Creek. Southeastern Archaeology 29(1): 8-30.

Braun D. P. 1980. Appendinx I: Experimental Interpretation of Ceramic Vessel Use on the Basis of Rim and Neck Formal Attributes. In D. C. Fiero, R. W. Munson, M. T. McClain, S. M. Wilson and A. H. Zier (eds.), The Navajo Project: Archaeological Investigations Page to Phoenix 500 KV Southern Transmission Line. Museum of Northern Arizona. Flagstaff: 171-231.

Braun G. 2010. Technological Choices: Ceramic Manufacture and Use at the Antrex Site (AjGv-38). Ontario Archaeology 89/90: 69-96.

Budja M., Ogrinc N., Žibrat Gašparič A., Potočnik D., Žigon D. and Mlekuž D. 2013. Transition to farming - transition to milk culture: a case study from Mala Triglavca, Slovenia. Documenta Praehistorica 40: 97-117.

Budja M. 2014. Neolithic pottery and the biomolecular archaeology of lipids. Documenta Praehistorica 41: 195224.

Costin C. L. 2000. The Use of Ethnoarchaeology for the Archaeological Study of Ceramic Production. Journal of Archaeological Method and Theory 7(4): 377-403.

Dimitrijević S. 1979. Sjeverna zona. In A. Benac (ed.), Praistorija jugoslavenskih zemalja II, Neolitsko doba. Akademija Nauka i Umjetnosti Bosne i Hercegovine, Centar za Balkanološka Ispitivanja. Sarajevo: 227-360.

Domboróczki L. 2010. Report on the excavation at Tiszaszólős-Domaháza-puszta and a new model for the spread of the Körös culture. In J. K. Kozłowski, P. Raczky (eds.), Neolithization of the Carpathian basin: Northernmost distribution of the Starčevo/Körös Culture. Papers presented on the symposium organized by the EU Project FEPRE (The formation of Europe: prehistoric population dynamics and the roots of Socio-Cultural diversity). Kraków. Budapest: 137-176.

Eerkens J. W. 2005. GC-MS analysis and fatty acid ratios of archaeological potsherds from the western Great Basin of North America. Archaeometry 47(1): 83-102.

Fahy Bryceson D., Howe J. 1993. Rural Household Transport in Africa: Reducing the Burden on Woman? World Development 21(11): 1715-1728.

Garašanin M. 1951. Hronologija Vinčanske grupe. Unpublished $\mathrm{PhD}$ thesis. University of Ljubljana. Ljubljana.

Hally D. J. 1983a. Use Alteration of Pottery Vessel Surfaces: An Important Source of Evidence for the Identification of Vessel Function. North American Archaeologist 4(1): 326.

1983b. The Interpretive Potential of Pottery from Domestic Contexts. Midcontinental Journal of Archaeo$\log y$ 8(2): 163-96.

1986. The Identification of Vessel Function: A Case Study from Northwest Georgia. American Antiquity 51(2): 267-95.

Hegmon M. 2000. Advances in Ceramic Ethnoarchaeology. Journal of Archaeological Method and Theory 7(3): 129-137.

Henrickson E. F., McDonald M. M. A. 1983. Ceramic Form and Function: An Ethnographic Search and an Archaeological Application. American Anthropologist 85: 630-643.

Horejs B. 2010. Possibilities and Limitations in Analysing Ceramic Wares. In B. Horejs, R. Jung and P. Pavúk (eds.), Analysing pottery. Processing - Classification - Publication. Studia Archaeologica et Medievalia 10. Comenius University in Bratislava. Bratislava: 15-28.

Horvat M. 1999. Keramika. Tehnologija keramike, tipologija lončenine, keramični arhiv. Razprave filozofske fakultete. Znanstveni inštitut Filozofske fakultete Ljubljana. Ljubljana.

Kalicz N. 1983/1984. Übersicht über den Forschungsstand der Entwicklung der Lengyel-Kultur und die Ältesten "Wehranlagen" in Ungarn. Mitteilungen der Österreichischen Gesellschaft für Ür- und Frühgeschichte 33/34: 271-293.

1992. Die Balaton-Lasinja-Kultur und ihre südlichen Beziehungen. Studia Praehistorica: 313-333. 
Kalicz N., Kreiter E. and Tokai Z. M. 2007. Die Rolle der Sopot-Kultur in der Entstehung der Lengyel-Kultur auf Grund der neuen Ausgrabungen in Südwestungarn. In J. K. Kozłovski, P. Raczky (eds.), The Lengyel, Polgár and related cultures in the Middle/Late Neolithic in Central Europe. The Polish Academy of Arts and Sciences Kraków. Eötvös Loránd University Institute of Archaeological Sciences Budapest. Kraków: 29-48.

Keršič I. 1988-1990. Oris stanovanjske kulture slovenskega kmečkega prebivalstva v 19. stol. Slovenski etnograf 33/34: 329-388.

Koprivnik V., Strmčnik Gulič M. and Kajzer Cafnik M. 2009. Aktualna arheološka odkritja. Muzejski listi 35. Maribor.

Korošec J. 1951. Prazgodovinska naselbina na Ptujskem gradu. Dela/Opera 6. Slovenska akademija znanosti in umetnosti, razred zgodovinske in družbene vede. Ljubljana.

Kramberger B. 2010. Zgornje Radvanje, Cluster 10 - a Late Neolithic pit with a structure and smaller pits. Documenta Praehistorica 37: 311-338.

2014. The Neolithic-Eneolithic sequence and pottery assemblages in the fifth millenium BC in north-eastern Slovenia. Documenta Praehistorica 41: 225-282.

2015. Svetilka iz zgodnjeeneolitske naselbine Zgornje Radvanje v Mariboru / Eine Lampe aus der früh-äneolithischen Siedlung von Zgornje Radvanje in Maribor. Arheološki vestnik 66: 249-273.

Lenneis E. 1999. Altneolithikum: Die Bandkeramik. In E. Lenneis, C. Neugebauer-Maresch and E. Ruttkay (eds.), Jungsteinzeit im Osten Österreichs. Forschungsberichte zur Ur- und Frühgeschichte 17. Wissenschaftliche Schriftenreihe Niederösterreich. St. Pölten - Wien: 11-56.

2010. Zur Chronologie der älteren Linearbandkeramik in Österreich. In J. Sutekova, P. Pavuk, P. Kalabkova and B. Kovar (eds.), Panta Rhei: Studies in Chronology and Cultural Development of South-Eastern and Central Europe in Earlier Prehistory Presented to Juraj Pavúk on the Occasion of his $75^{\text {th }}$ Birthday. Studia Archaeologica et Mediaevalia 11. Comenius University in Bratislava. Bratislava: 189-200.

Lis B. 2010. Cooking pottery in the Late Bronze Age Aegean - an Attempt at a Methodological Approach. In B. Horejs, R. Jung and P. Pavúk (eds.), Analysing pottery. Processing - Classification - Publication. Studia Archaeologica et Medievalia 10. Comenius University in Bratislava. Bratislava: $235-244$.
Lloyd R., Parr B., Davies S. and Cooke C. 2010. No 'free ride' for African women: A comparison of head-loading versus back-loading among Xhosa women. South African Journal of Science 106(3/4): 1-5.

Makarovič G. 1988-1990. Prehrana v 19. stol. na Slovenskem. Slovenski etnograf 33/34: 127-205.

Marić M. 2013. Zaštitna arheološka istraživanja na lokalitetu Jaričište 1 / Rescue excevations on the Jaričište 1 site. In B. Filipović, P. Arsić and D. Antonović (eds.), Rezultati novih arheoloških istraživanja u severozapadnoj Srbiji i susednim teritorijama. Srpsko arheološko duštvo. Zavod za zaštitu spomenika Valjevo. Beograd, Valjevo: $17-31$.

Mlekuž D., Žibrat Gašparič A., Horvat M. and Budja M. 2012. Houses, pots and food: the pottery from Maharski prekop in context. Documenta Praehistorica 39: 325338.

Mlekuž D., Ogrinc N., Horvat M., Žibrat Gašparič A., Gams Petrišič M. and Budja M. 2013. Pots and food: uses of pottery from Resnikov prekop. Documenta Praehistorica 40: 131-146.

Murko M. 2012. Maribor - arheološko najdišče Zgornje Radvanje. Varstvo spomenikov 47: 139-142.

Nagy Gyula K. 1911. Az ó-bes-senyői őstelep (Hat képes táblával és nyolcz ábrával). Archaeológiai Értesitó 31(2): 147-164.

Neugebauer J.-W., Schöfmann H. 1981. Niederkreuzstetten. Fundberichte aus Österreich 19(1980): 344-347.

Neumair E. 1997. Bedeutende Siedlungsfunde der Münchshöfener Kultur aus Murr. Das archaölogische Jahr in Bayern 1996: 43-45.

Ogrinc N., Budja M. 2005. Paleodietary reconstruction of a Neolithic population in Slovenia: a stable isotope approach. Chemical geology 218: 103-116.

Ogrinc N., Gams Petrišič M., Žigon D., Žibrat Gašparič A. and Budja M. 2012. Pots and lipids: molecular and isotope evidence of food processing at Maharski prekop. Documenta Praehistorica 39: 339-347.

Ogrinc N., Budja M., Počnik D., Žibrat Gašparič A. and Mlekuž D. 2014. Lipids, pots and food processing at Hočevarica, Ljubljansko barje, Slovenia. Documenta Praehistorica 41: 181-194.

Oudemans T. F. M., Boon J. J. 1993. Traces of Ancient Vessel Use: Investigating Prehistorie Usage of four Pot Types by Organic Residue Analysis using Pyrolysis Mass Spectrometry. Analecta Praehistorica Leidensia 26: 221-234. 
Pahič S. 1976. Seliščne najdbe v zahodnih Slovenskih goricah - Andrenci, Spodnji Duplek, Spodnji Porčič, Vumpah. Poročilo o raziskovanju paleolita, neolita in eneolita $v$ Sloveniji 5: 29-83.

Pavúk J. 1981. Súčasný stav štúdia Lengyelskej kultúry na Slovensku (The present state of knowledge of the Lengyel culture in Slovakia). Památky archeologicke 72: 255-299.

Plestenjak A. 2010. Gorice pri Turnišču. Zbirka Arheologija na avtocestah Slovenije 12. Zavod za varstvo kulturne dediščine Slovenije. Ljubljana.

Podborský V. 1970. Současný Stav výzkumu kultury s Moravskou Malovanou keramikou. Slovenská archeológia 18(2): 241-287.

Raetzel-Fabian D. 1988. Die ersten Bauernkulturen. Jungsteinzeit in Nordhessen. Katalog der Staatlichen Kunstsammlung. Kassel.

Rakovský I. 1986. Die Neige der Älteren Stufe der Kultur mit Mährischer Bemalter Keramik im Lichte der Funde aus Jezeřany-Maršovice und Brno-Bystrc. In Internationales symposium uber die Lengyel-Kultur. Nitra-Wien: 61-67.

Rice P. M. 1987. Pottery Analysis, A Sourcebook. The University of Chicago Press. Chicago. London.

Ruttkay E. 1974/1975, Das Neolithikum in Niederösterreich - Forschungsbericht der letzen 25 Jahre. Mitteilungen der Österreichischen Arbeitsgemeinschaft für Urund Frühgeschichte 25(1): 41-57.

1976. Die Keramikformen der Lengyel-Kultur in Österreich. Fundberichte aus Österreich 15: 141-148.

Sălceanu I. 2008. Sălcuţa IV - Herculane II-III. Seria "MONOGRAPHIA" 1. Satu Mare.

Schiffer M., Skibo J. 1987. Theory and Experiment in the Study of Technological Change. Current Anthropology 28 (5): 595-622.

Shapiro G. 1984. Vessels, Site Permanance, and Group Size: A Mississippian Example. American Antiquity 49(4): 696-712.

Smith M. F. Jr. 1988. Function from Whole Vessel Shape: A Method and an Application to Anasazi Black Mesa, Arizona. American Anthropologist 90: 912-923.

Stadler P., Ruttkay E. 2007. Absolute chronology of the Moravian-Eastern-Austrian Group (MOG) of the painted pottery (Lengyel-culture) based on new radiocarbon dates from Austria. In J. K. Kozłovski, P. Raczky (eds.), The Lengyel, Polgár and related cultures in the Middle/Late Neo- lithic in Central Europe. The Polish Academy of Arts and Sciences Kraków, Eötvös Loránd University Institute of Archaeological Sciences Budapest. Kraków: 117-146.

Sterle M. 1987. Prehrana na Loškem. Loški razgledi 34: 105-161.

Šavel I. 1992. Bukovnica - rezultati terenskih raziskav v letih 1987 - 1988. Poročilo o raziskovanju paleolita, neolita in eneolita $v$ Sloveniji 20: 57-85.

1994. Prazgodovinske naselbine v Pomurju. Pomurska založba. Murska Sobota.

Šavel I., Sankovič S. 2011. Pri Muri pri Lendavi. Zbirka Arheologija na avtocestah Slovenije 23. Zavod za varstvo kulturne dediščine Slovenije. Ljubljana.

Šoberl L., Žibrat Gašparič A., Budja M. and Evershed R. P. 2008. Early herding practices revealed through organic residue analysis of pottery from the early Neolithic rock shelter of Mala Triglavca, Slovenia. Documenta Praehistorica 35: 253-260.

Šoberl L., Horat M., Žibrat Gašparič A., Sraka M., Evershed R. and M. Budja 2014. Neolithic and Eneolithic activities inferred from organic residue analysis of pottery from Mala Triglavca, Moverna vas and Ajdovska jama, Slovenia. Documenta Praehistorica 41: 149-179.

Tomaž A. 2010. Neolitska keramika iz najdišča ČatežSredno polje: prispevek $k$ poznavanju neolitskega obdobja v osrednii Sloveniji. Unpublished PhD thesis. University of Primorska, Koper.

2012. Turnišče. Zbirka Arheologija na avtocestah Slovenije 28. Zavod za varstvo kulturne dediščine Slovenije. Ljubljana.

Urem-Kotsou D., Kotsakis K. and Stern B. 2002. Defining function in Neolithic ceramics: the example of Makriyalos, Greece. Documenta Praehistorica 29: 109-118.

Wilson G. D. 1999. The Production and Consumption of Mississippian Fineware in the American Bottom. Southeastern Archaeology 18(2): 98-109.

Wilson G. D., Rodning C. B. 2002. Boiling, Baking and Pottery Braking: A Functional Analysis of Ceramic Vessels from Coweta Creek. Southeastern Archaeology 21(1): 29-35.

UN-Water/WWAP/WWDR2/poster/2006/4, www.unesco. org/water/wwap, Water: The Challenges. World Water Assessment Programme. 12: Gender and primary education in Ethiopia. Photo: M. Marzot. 


\section{Appendix}
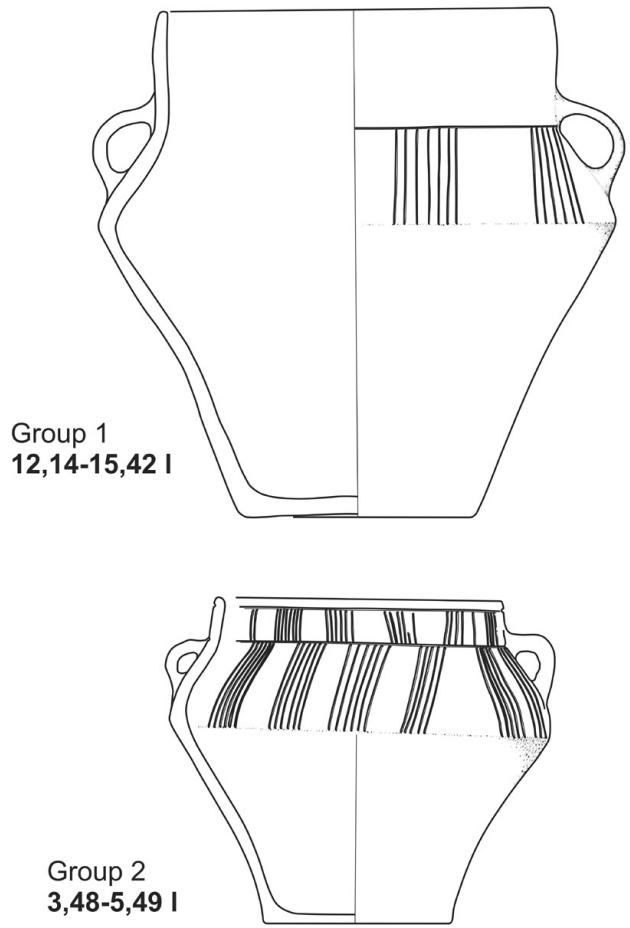

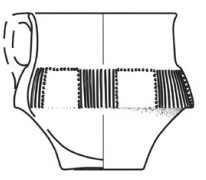

Group 1 $0,43-0,47$

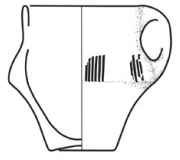

Group 2 0,22-0,23
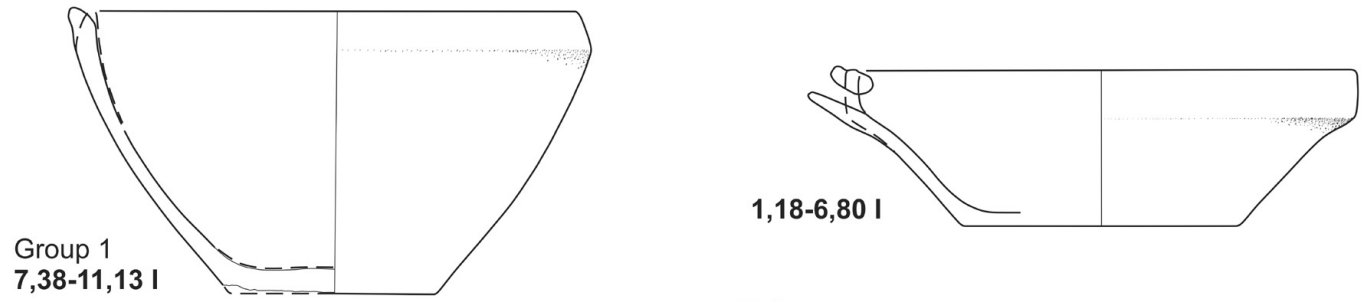

7,38-11,13 I

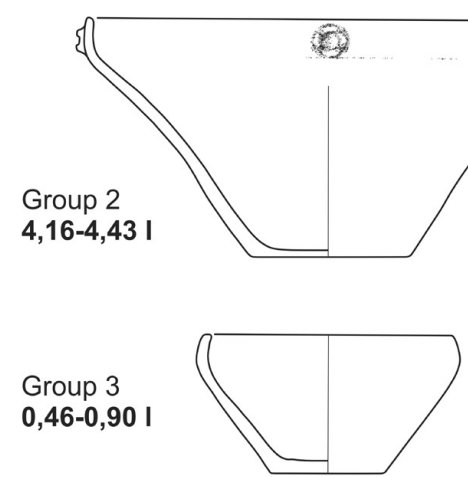

Bowls

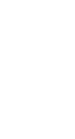

0,14-0,16 I

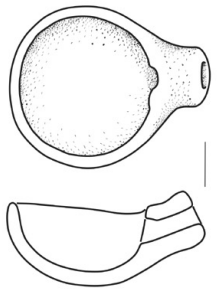

Ladles

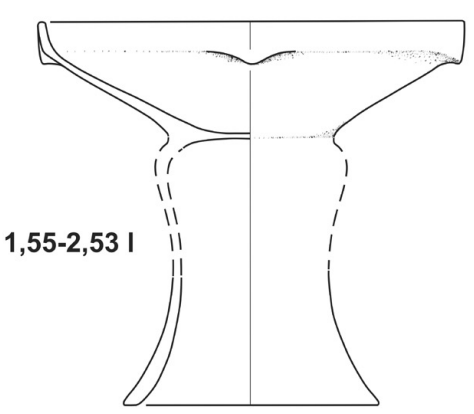

Pedestal dishes

App. 1. Pots, a Butte, pitchers, bowls, dishes, pedestal dishes, ladles and their volumes. Scale 1:6. 


\begin{tabular}{|c|c|c|c|c|c|}
\hline Vessel type & Context & $\begin{array}{l}\text { Drawing } \\
\text { Code }\end{array}$ & $\begin{array}{l}\text { Volume } \\
\text { in litres }\end{array}$ & $\begin{array}{l}\text { Size of } \\
\text { orifice }\end{array}$ & Reference \\
\hline pot & Structure 9 (SE 553) & $384 \mathrm{~A}$ & $15,42 \mid$ & $21,9 \mathrm{~cm}$ & - \\
\hline pot & Structure 5 (SE 271) & B 16 & 15,301 & $23 \mathrm{~cm}$ & Kramberger 2010.PI. 8.51 \\
\hline pot & Structure 3 (SE 544) & $1123 \mathrm{~A}$ & 12,71 I & $23,4 \mathrm{~cm}$ & - \\
\hline pot & Structure 5 (SE 324) & B 165 & $12,14 \mid$ & $24 \mathrm{~cm}$ & Kramberger 2010.Pl. 2.12 \\
\hline pot & Structure 1 (SE 599) & $1065 \mathrm{~A}$ & 5,491 & $16,5 \mathrm{~cm}$ & Kramberger 2014.PI. 9.152 \\
\hline pot & Structure 11-15 (SE 786) & $716 \mathrm{~A}=719 \mathrm{~A}$ & 5,471 & $17,4 \mathrm{~cm}$ & - \\
\hline pot & Structure 22 (SE 853) & $1292 \mathrm{~A}$ & 5,421 & $15,6 \mathrm{~cm}$ & Kramberger 2014.PI. 7.122 \\
\hline pot & Structure 5 (SE 324) & B 108 & 4,971 & $17 \mathrm{~cm}$ & Kramberger 2010.PI. 4.20 \\
\hline pot & Structure 4 (SE 1128) & $561 \mathrm{~A}$ & 4,821 & $16,5 \mathrm{~cm}$ & Kramberger 2014.PI. 9.146 \\
\hline pot & Structure 5 (SE 271) & B $122=$ B 107 & 4,661 & $16,2 \mathrm{~cm}$ & Kramberger 2010.PI. 7.48 \\
\hline pot & Structure 5 (SE 324) & B 443 & 4,211 & $17,4 \mathrm{~cm}$ & Kramberger 2010.Pl. 3.18 \\
\hline pot & Structure 6 (SE 226) & $37 \mathrm{~A}=45 \mathrm{~A}$ & 3,531 & $15 \mathrm{~cm}$ & Kramberger 2014.PI. 8.131 \\
\hline pot & Structure 5 (SE 27) & B 444 & 3,481 & $16 \mathrm{~cm}$ & Kramberger 2010.PI. 9.52 \\
\hline pot & Structure 20 (SE 1420) & $1620 \mathrm{~A}$ & 2,281 & $15 \mathrm{~cm}$ & - \\
\hline pot & Structure 5 (SE 271) & B $158=$ B 94 & 0,811 & $11 \mathrm{~cm}$ & Kramberger 2010.PI. 7.46 \\
\hline Butte & Structure 20 (SE 1458) & 41 & 13,631 & $18 \mathrm{~cm}$ & - \\
\hline pitcher & Structure 7 (SE 18) & $79 \mathrm{~A}=87 \mathrm{~A}$ & 0,471 & $9 \mathrm{~cm}$ & Kramberger 2014.PI. 8.135 \\
\hline pitcher & Structure 22 (SE 820) & $1257 \mathrm{~A}$ & 0,44 I & $9 \mathrm{~cm}$ & Kramberger 2014. Pl. 7.116 \\
\hline pitcher & Structure 4 (SE 1128) & $558 \mathrm{~A}$ & 0,231 & $6,6 \mathrm{~cm}$ & - \\
\hline pitcher & Structure 5 (SE 27י) & B $10=$ B 194 & 0,221 & $6,9 \mathrm{~cm}$ & Kramberger 2010. Pl. 7.42 \\
\hline bowl (with a spout) & Structure 9 (SE 546) & $284 \mathrm{~A}$ & $11,13 \mid$ & $34,5 \mathrm{~cm}$ & - \\
\hline bowl (with a spout) & Structure 4 (SE 1128) & $521 \mathrm{~A}$ & 7,381 & $30 \mathrm{~cm}$ & - \\
\hline bowl (with appliqués) & Structure 5 (SE 271) & $B_{57}=B_{3}$ & 4,431 & $30 \mathrm{~cm}$ & Kramberger 2010.PI. 4.23 \\
\hline bowl (with appliqués) & Structure 5 (SE 324) & B $174=B 18$ & 4,381 & $23 \mathrm{~cm}$ & Kramberger 2010.PI. 1.6 \\
\hline bowl & Structure 17 (SE 1435) & $1840 \mathrm{~A}$ & 4,161 & $26,4 \mathrm{~cm}$ & - \\
\hline bowl & Structure 20 (SE 1458) & $1454 \mathrm{~A}$ & 0,901 & $15,3 \mathrm{~cm}$ & - \\
\hline bowl & Structure 5 (SE 271) & B 26 & 0,821 & $15,3 \mathrm{~cm}$ & Kramberger 2010.PI. 5.27 \\
\hline bowl (with handles) & Structure 17 (SE 1435) & $1854 \mathrm{~A}$ & 0,791 & $12,6 \mathrm{~cm}$ & - \\
\hline $\begin{array}{l}\text { bowl (with small } \\
\text { perforated handles) }\end{array}$ & Structure 9 (SE 546) & $391 \mathrm{~A}$ & 0,461 & $13,2 \mathrm{~cm}$ & - \\
\hline dish (with a spout) & Structure 4 (SE 1128) & $560 A=556 A$ & 6,801 & $33,3 \mathrm{~cm}$ & Kramberger 2014.PI. 9.143 \\
\hline dish (with a spout) & Structure 3 (SE 425) & $1124 \mathrm{~A}$ & $4,14 I$ & $31,5 \mathrm{~cm}$ & - \\
\hline dish (with a spout) & Structure 4 (SE 1128) & $559 A$ & $3,17 \mid$ & $27 \mathrm{~cm}$ & Kramberger 2014.PI. 9.145 \\
\hline dish & Structure 17 (SE 1414) & $1787 \mathrm{~A}$ & 1,981 & $22,5 \mathrm{~cm}$ & - \\
\hline dish (with a spout) & Structure 20 (SE 1458) & $1672 \mathrm{~A}$ & $1,18 \mid$ & $20,1 \mathrm{~cm}$ & - \\
\hline pedestal dish & Structure 3 (SE 425) & $\begin{array}{c}1164 \mathrm{~A}=1131 \mathrm{~A}= \\
=\mathrm{dš} 1\end{array}$ & 2,531 & $28,5 \mathrm{~cm}$ & - \\
\hline pedestal dish & Structure 11-15 (SE 1329) & $807 \mathrm{~A}$ & 2,461 & $26 \mathrm{~cm}$ & - \\
\hline pedestal dish & Structure 4 (SE 1128) & $522 \mathrm{~A}$ & $2,44 \mid$ & $28,5 \mathrm{~cm}$ & Kramberger 2014.PI. 9.142 \\
\hline pedestal dish & Structure 11-15 (SE 786) & $725 \mathrm{~A}$ & 2,031 & $25,5 \mathrm{~cm}$ & - \\
\hline pedestal dish & $\begin{array}{c}\text { Structure } 9 \\
(\mathrm{SE} 553 \text { and SE 546) }\end{array}$ & $373 \mathrm{~A}$ & 1,931 & $26 \mathrm{~cm}$ & - \\
\hline pedestal dish & $\begin{array}{c}\text { Structure } 9 \\
\text { (SE } 553 \text { and SE 468) }\end{array}$ & $352 \mathrm{~A}=328 \mathrm{~A}$ & 1,661 & $22,2 \mathrm{~cm}$ & - \\
\hline pedestal dish & Structure 5 (SE 27) & В 159 & 1,551 & $22,5 \mathrm{~cm}$ & Kramberger 2010.PI. 6.33 \\
\hline ladle & Structure 5 (SE 271) & B 452 & 0,161 & $11 \mathrm{~cm}$ & Kramberger 2010. Pl. 9.53 \\
\hline ladle & Structure 1 (SE 599) & $1851 \mathrm{~A}$ & $0,14 I$ & $9,4 \mathrm{~cm}$ & Kramberger 2014.PI. 9.151 \\
\hline
\end{tabular}

